Florida State University College of Law

Scholarship Repository

Scholarly Publications

Summer 2015

\title{
A Deficiency in Addressing Campus Sexual Assault: The Lack of Women Law Enforcement Officers
}

Nat Stern

Florida State University College of Law

Karen Oehme

Follow this and additional works at: https://ir.law.fsu.edu/articles

Part of the Criminal Law Commons, Law and Gender Commons, and the Law and Society Commons

\section{Recommended Citation}

Nat Stern and Karen Oehme, A Deficiency in Addressing Campus Sexual Assault: The Lack of Women Law Enforcement Officers, 38 HARV. J.L. \& GENDER 337 (2015),

Available at: https://ir.law.fsu.edu/articles/445

This Article is brought to you for free and open access by Scholarship Repository. It has been accepted for inclusion in Scholarly Publications by an authorized administrator of Scholarship Repository. For more information, please contact efarrell@law.fsu.edu. 


\title{
A DEFICIENCY IN ADDRESSING CAMPUS SEXUAL ASSAULT: THE LACK OF WOMEN LAW ENFORCEMENT OFFICERS
}

\author{
Karen Oehme, ${ }^{*}$ Nat Stern, ${ }^{* *}$ Annelise Mennicke***
}

The federal government has taken a range of measures to combat the scourge of sexual assault afflicting college campuses across the nation. Whatever the efficacy of these policies, however, they fail to address a major obstacle to curbing sexual violence on campus: the chronically low rate of reporting of this crime to police. Research on crime data has produced evidence that as female representation among police officers increases, more crimes against women are reported. Yet, most university campus law enforcement agencies-tasked with taking a "central role" in combatting sexual assault-include strikingly few female officers. This Article proposes an increase in women's representation in campus police agencies to foster more reporting by victims and argues that schools failing to demonstrate consistent, ongoing, and genuine efforts to hire female officers are contributing to a hostile environment for complainants in Title IX litigation.

\section{TABLE of Contents}

Introduction

1. The Federal Response to Rampant Sexual Assault at

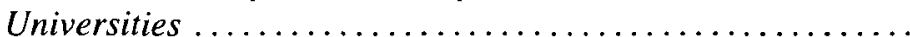

II. The Problem of Underreporting ................ 347

III. The Impact of Women Officers on Sexual Assault Reporting .................................. 350

IV. A Call for More Women Officers on Campus ........... 357 Conclusion ........................................... 371

\section{INTRODUCTION}

Sexual violence is harrowingly common in the United States, where a sexual assault occurs about every two minutes.' Nearly one in five women

* Director, Florida State University Institute for Family Violence Studies; Florida State University Distinguished University Scholar. Law.

** John W. and Ashley E. Frost Professor of Law, Florida State University College of

*** Doctoral candidate, Florida State University College of Social Work.

The authors wish to thank Delaney Ellen Anderson for her outstanding research assistance.

${ }^{1}$ Statistics, RAPE, ABUSE \& InCEST NAT'L. NETwORK, https://rainn.org/statistics, archived at https://perma.cc/28TA-4BJ9 (also noting that there are about 293,000 victims of sexual assault each year). 
(18.3\%) and one in seventy-one men $(1.4 \%)$ have been raped. ${ }^{2}$ Rape is such a common crime that researchers have hypothesized that women live under a "shadow of sexual assault" that influences how they think about their risk for victimization and crime generally. ${ }^{3}$ Sexual violence on campus is an especially visible instance of this grimly pervasive phenomenon in American society. Like victims elsewhere, college and university students who are sexually assaulted suffer varied and often protracted traumatic injuries. ${ }^{4}$ What their experience highlights in particular is the serious problem of chronic underreporting of this crime. Colleges have an explicit responsibility to work to prevent sexual harassment (including sexual assault); 5 they need to know about the perpetration of such crimes in order to achieve that goal.

As the country responds to a crisis of sexual assault on college campuses that has reached "epidemic proportions," ${ }^{\circ}$ a flood of federal policy recommendations and laws to increase prevention, arrest, prosecution, and victim services have taken aim at this widespread crime. Though all of these recent steps are important, this Article contends that the reporting of the crime to police_-arguably the most critical step in reducing it —will remain chronically low unless a significant gap in law and campus policy is addressed. Unfortunately, even the most stringent response to sexual assault will accomplish little unless policies exist to ensure that student victims feel comfortable reporting this devastating crime. Part One of this Article describes federal efforts to address sexual assault on American college and university campuses and increase prevention and intervention efforts. Part Two describes the prevalence of sexual assault on campuses, its effects on victims, and the costs of the disturbingly low reporting rates for the crime. Part Three describes the low numbers of female officers in campus law enforcement agencies, research on how women officers respond to victims, and new research on long-term crime data showing that reporting of crimes against women increases as female representation among officers increases. Part Four argues for an immediate increase in women's representation in campus police agencies to promote more reporting by victims and asserts that schools that do not demonstrate consistent, ongoing, and genuine efforts to hire female officers are contributing to a hostile environment for complainants in Title IX litigation.

2 D. Kelly Weisberg, Domestic Violence: Legal and Social Reality 30 (2012).

${ }^{3}$ See Bonnie S. Fisher \& John J. Sloan, III, Unraveling the Fear of Victimization Among College Women: Is the "Shadow of Sexual Assault Hypothesis" Supported?, 20 JusT. Q. 633, 634 (2003).

${ }^{4}$ See infra note 76 and accompanying text.

${ }^{5}$ See infra notes 42-70 and accompanying text.

${ }^{6}$ Kristen Lombardi, Flurry of New Legislation Targets Sexual Assault on Campus, CTR. FOR PUB. INTEgrity (July 30, 2014), http://www.publicintegrity.org/2014/07/30/ 15185/flurry-new-legislation-targets-sexual-assault-campus, archived at http://perma.cc/ Q7DT-N8PS (quoting statement of Congresswoman Carolyn Maloney, D-NY). 


\section{The Federal Response to Rampant Sexual Assault AT UNIVERSITIES}

The federal government has enacted several pieces of legislation intended to curb sexual violence at universities. While these laws represent constructive steps toward addressing this crime, they have left gaps that must be filled by other means. An increase in women's representation in campus police agencies would be such a supplemental approach. For the reasons discussed later in this Article, ${ }^{7}$ a higher proportion of women in the ranks of campus police would serve a need not met by existing federal regulation.

Both federal legislation and increasing the number of women in campus police agencies, of course, seek to improve the manner in which colleges and universities address sexual violence in their midst. Reporting sexual assault is an essential first step in obtaining services for victims and holding perpetrators accountable. Without reporting, victims remain voiceless. Unfortunately, many institutions have done an inadequate - even abysmal-job of dealing with sexual assaults that are reported. A recent study indicated that the ordinary practice of universities is to undercount incidents of sexual assault; only during periods in which schools are audited do they appear to offer a more complete picture of sexual assault levels on campus. ${ }^{8}$ In 2010 , the Center for Public Integrity conducted an investigation into campus sexual assaults. ${ }^{9}$ In addition to interviewing experts on campus disciplinary policies and female victims, they reviewed U.S. Department of Education records of sexual assault complaints filed against colleges and universities. ${ }^{10}$ Among other findings, the Center reported that students who were found to be responsible for the sexual assault of other students were rarely punished." In fact, the perpetrators tended to remain on campus, while the victims often dropped out of school. ${ }^{12}$ Universities expelled only a fraction of the perpetrators, about ten to twenty-five percent. ${ }^{13}$ Universities have been sharply criticized for their alleged lack of concern for victims. ${ }^{14}$ Reflecting the

${ }^{7}$ See infra Parts III, IV.

${ }^{8}$ See Corey Rayburn Yung, Concealing Campus Sexual Assault: An Empirical Examination, 21 PSYCHOL. PUB. Pol.'y \& L. 1, 6 (2015).

${ }^{9}$ Kristen Lombardi, A Lack of Consequences for Sexual Assault, CTr. For PUB. INTEGRITY (Feb. 24, 2010), http://www.publicintegrity.org/2010/02/24/4360/lack-conse quences-sexual-assault, archived at http://perma.cc/NR2X-4K $5 \mathrm{X}$.

${ }^{10}$ See id.

"See id.

${ }^{12}$ See Ctr. for Pub. Integrity, Sexual Assault on Campus: A Frustrating SEARCh For Justice 56-57 (Gordon Witkin \& David Donald eds., 2010), archived at http://perma.cc/7DFM-2RL2.

${ }_{13}^{13}$ See id.

${ }^{14}$ See, e.g., Walt Bogdanich, A Star Player Accused, and a Flawed Rape Investigation, N.Y. Times, Apr. 16, 2014, archived at http://perma.cc/85ZY-JMYR [hereinafter Bogdanich, A Star Player Accused] (examining a Florida State University student's report that a football player had sexually assaulted her and finding that "there was virtually no investigation at all, either by the police or the university"); Walt Bogdanich, Report- 
magnitude of this issue, media outlets and newspapers in 2014 published countless articles on the issue of campus sexual assault and the government's response to the epidemic. ${ }^{15}$

ing Rape, and Wishing She Hadn't, N.Y. Times, July 12, 2014, archived at http://perma .cc/USJ7-976H (reporting on a freshman's report of sexual assault by a football player at Hobart and William Smith Colleges and finding "the internal records ... depict a school ill prepared to evaluate an allegation so serious"); Matthew Albright, Feds Study UD's Handling of Sexual Violence Complaints, DEL. ONLINE (June 6, 2014), http://www.delawareonline.com/story/news/local/2014/06/06/feds-probe-uds-handling-sexual-violencecomplaints/10079821/, archived at http://perma.cc/Y8V4-5G8S ("Universities, speaking generally, have been a really problematic area for sexual assault."); Tyler Kingkade, Education Department Investigating Claims UC Berkeley Botched Sexual Assault Reports, HuFFington POST (Apr. 21, 2014), http://www.huffingtonpost.com/2014/04/21/uc-berkeley-investigationsexual-assault_n_5185990.html, archived at http://perma.cc/D2XR$86 \mathrm{KH}$ (stating that University of California Berkeley is being investigated for Title IX complaints from thirty-one students alleging "there was little to no response on the part of the university when students reported rape, sexual assault and ongoing harassment on campus"); Tyler Kingkade, Emerson College Slammed in Lawsuit over Handling of Rape Case, HuFFington Post (Aug. 12, 2014), http://www.huffingtonpost.com/2014/08/12/ emerson-college-lawsuitrape_n_5671580.html, archived at http://perma.cc/Z9UR-RK9N (stating that Emerson College is being sued by a student for mishandling her sexual assault case, causing her such extreme stress that she had to be hospitalized); Tyler Kingkade, For Years, Students Have Accused Virginia Universities of Botching Sexual Assault Cases, Huffington Post (July 1, 2014), http://www.huffingtonpost.com/2014/07/01/virginia-universities-sexualassault_n_5545486.html, archived at http://perma.cc/RBQ62N5E ("Students have been suspended for drinking offenses, and expelled for plagiarism, and [failure to expel students found responsible for sexual assaults] sends the message to the university community that sexual assault is not as serious as these other behaviors."); Tyler Kingkade, Virginia Wesleyan College Helped Accused Rapist by Erasing Expulsion from His Record, Huffington Post (Oct. 6, 2014), http://www.huffingtonpost.com/ 2014/10/06/virginia-wesleyan-rape_n_5940404.html, archived at http://perma.cc/RWN42JCA (quoting the victim of a sexual assault at Virginia Wesleyan College, "You're [referring to college officials] going to help my rapist, yet l'm struggling ... and you aren't helping me").

${ }^{15}$ See, e.g., Robin Abcarian, New Sex Rules for California College Students Are Long Overdue, L.A. TimEs, Sept. 30, 2014, archived at http://perma.cc/T77N-SUCL (reporting on the new California legislation requiring California colleges to have a consistent message about the meaning and importance of consent during sexual activity); Nick Anderson, Campus Discussions Increasingly Focus on Sex Assault, WAsH. Post, Sept. 26, 2014, archived at http://perma.cc/NEN9-PWX4 (reporting one college's use of discussions on campus to address sexual assault and students' perceptions of the current climate); Nick Anderson \& Katie Zezima, White House Issues Report on Steps to Prevent Sexual Assaults on College Campuses, WASH. Post, Apr. 29, 2014, archived at http://per ma.cc/75UB-GTJY (reporting on the White House Task Force to Protect Students from Sexual Assault and its report on the issues surrounding campus sexual assault); Bogdanich, A Star Player Accused, supra note 14 (reporting on one student's experience of reporting her rape to her college administration); Michael D. Shear \& Elena Schneider, Obama Unveils Push for Young People to Do More Against Campus Assaults, N.Y. Times, Sept. 19, 2014, archived at http://perma.cc/WBU4-JW4D (reporting on President Obama's announcement of the "It's on Us" campaign, which encourages young people to "feel a sense of responsibility to confront the problem of sexual assault"); Victor Romano \& Laura Finley, Onus of Changing Campus Rape Culture Lies with Men, MiAmI HerAid, Oct. 1, 2014, archived at http://perma.cc/72XM-UK8K (commenting on the role of men in ending rape culture and the campus sexual assault problem); Eliza Gray, Colleges Are Breaking the Law on Sex Crimes, Report Says, Time (July 9, 2014), http://time.com/2969580/claire-mccaskill-campus-sexual-assault-rape/, archived at http:// perma.cc/7JNV- GKF6 (reporting on survey results that highlight colleges, and universi- 
In attempting to curb campus sexual assault and to protect victims, the federal government has acted in a variety of ways. For example, the government has recognized the importance of obtaining and disseminating information on campus crimes, as evidenced by the 1990 passage of the Jeanne Clery Disclosure of Campus Security and Campus Crime Statistics Act. ${ }^{16}$ The Act aimed to collect accurate statistics on campus crime to raise awareness about such crime. ${ }^{17}$ Under the Act, colleges and universities that participate in federal financial aid programs ${ }^{18}$ are required to record and disseminate information about crime on and near campus. ${ }^{19}$ The U.S. Department of Education monitors compliance with the Act. ${ }^{20}$ Violations of the Act can result in financial penalties of $\$ 35,000$ per violation. ${ }^{21}$ The Act requires a public record of all crimes reported to campus law enforcement; these include homicide, sex offenses, robbery, aggravated assault, motor vehicle theft, burglary, drug and liquor law violations, arson, and illegal weapons possession. ${ }^{22}$ The Clery Act, named after a young woman who was raped and murdered by another student in a university campus residence, has brought public attention to the risk of victimization on campus. ${ }^{23}$ Clery reports come from a variety of sources and primarily reflect only a statistical accounting

ties' mishandling of campus sexual assault reports and failure to follow statutory requirements); Eliza Gray, Why Victims of Rape in College Don't Report to the Police, Time. (June 23, 2014), http://time.com/2905637/campus-rape-assault-prosecution/, archived at http://perma.cc/BUM3-WVDL [hereinafter Gray, Why Victims Don't Report] (reporting on the roundtable discussion hosted by Sen. McCaskill about law enforcement involvement in campus sexual assaults).

${ }^{16}$ Jeanne Clery Disclosure of Campus Security Policy and Campus Crime Statistics Act, 20 U.S.C. $\S 1092(f)(2012)$.

${ }^{17}$ See id. $\$ \S 1092(f)(1), 1092(f)(5)(B)$; Fla. Atl. Univ., Clefry InCident Report 1 , archived at http://perma.cc/E8N5-2DBB ("One purpose of CLERY is to encourage reporting and the accurate collection of campus crime statistics to promote crime awareness and to enhance campus safety through reliable statistical records.").

${ }^{i 8}$ See id. \& 1092(f)(1) (stating the Act applies to "[e]ach eligible institution participating in any program under this subchapter and part $C$ of subchapter I of chapter 34 of title 42"); 42 U.S.C. $\$ \S 1070-1099$ e (Chapter 28, Subchapter IV) (2012) (describing federal financial aid and loan programs); 42 U.S.C. \$\$ 2751-2757 (Chapter 34, Subchapter I, Part C) (2012) (describing federal work-study programs).

${ }^{19} 20$ U.S.C. $\S 1092(f)(1)$.

${ }^{20}$ The Jeanne Clery Act, DARTmouth Coll. (Feb. 1 1, 2015), http://www.dartmouth .edu/sexualrespect/clery/, archived at http://perma.cc/UT7P-BCR9.

${ }_{21} 20$ U.S.C. $\$ 1094$ (c)(3)(B) (2012); 34 C.F.R. $\$ \S 36.1-2$ (2014). Recent legislation has proposed that these fines be increased to $\$ 150,000$. See The Bipartisan Campus Accountability and Safety Act, H.R. 5354, 113th Cong. \$2(5) (2014), archived at http://per ma.cc/2CPU-4ZNH.

2220 U.S.C. § 1092(f)(1). See also The Campus Safety and Security Data Analysis Cutting Tool, U.S. DEP'T Or EDUC., http://ope.ed.gov/security/, archived at http://perma .cc/3CY4-M98H (federal database collecting statistics on alleged criminal offenses reported to campus security authorities from postsecondary institutions that participate in federal student aid programs).

${ }^{23}$ See Carol E. Jordan, The Safety of Women on College Campuses: Implications of Evolving Paradigms in Postsecondary Education, 15 TRAumA, Violence, \& ABuse 143, 145 (2014) [hereinafter Jordan, The Safety of Women]. 
of crimes that happen on or near campus. ${ }^{24}$ It is common for campusesincluding universities among the largest in the nation-to report very small numbers of sexual assaults in Clery reports..$^{2.5}$

Additionally, the government has expanded longstanding prevention and victim services and established new guidelines for victim redress under civil rights laws. Expanded guidelines under Title IX of the Education Amendments of $1972^{26}$ were promulgated in 2011 and require schools receiving federal funding to promptly investigate sexual violence allegations and take immediate steps to address the effects of violence. ${ }^{27}$ The Violence Against Women Act ${ }^{28}$ (VAWA) - which for twenty years has provided funding for innovative programs to reduce rape, interpersonal violence, and stalking-has also improved the ability of universities to create a coordinated response to campus sexual assault and dating violence. ${ }^{29}$ Just as previous administrations have emphasized the need to reduce campus violence and protect victims, ${ }^{30}$ the Obama Administration weighed in directly on the issue of sexual assault in 2014 , calling on campus law enforcement to play a central role in responding to sexual assault. ${ }^{31}$

${ }^{24}$ See The Clery Act in Detail, KNow Your IX, http://knowyourix.org/the-clery-actin-detail/, archived at http://perma.cc/DR75-SGPZ.

${ }^{25}$ See, e.g., Ariz. State Univ., Annual. Security and Fire Safety Report 44 (2014), archived at http://perma.cc/34FKKJDK (reporting fifteen forcible sexual offenses in 2013 for the Tempe campus); Ohio State Univ., 2014 Annual Campus Security Report \& Annunl Fire SAFETy Report 54 (2014), available at http:/www.ps.ohiostate.edu/campus_safety/Annual_Security_Fire_Safety_Report.pdf (reporting twenty-five forcible sexual offenses in 2013); Univ. OF Minn., 2014 Annual Security and Fire Safety Report for the Minneapolis and St. Paul Campuses 41 (2014), available at https://police.umn.edu/sites/police.umn.edu/files/general/2014\%20Annual\%20Security\% 20 and $\% 20$ Fire\% 20 Safety\%20Report.pdf (reporting eighteen forcible sexual offenses in 2013).

${ }^{26} 20$ U.S.C. $\$ \S 1681-1688$ (2012). For further discussion, see infra note 49 and accompanying text.

${ }^{27}$ See Office for Civil Rights, U.S. Dep't of Enuc., Dear Collengue letter (2011), archived at https://perma.cc/5ZPHQLND?type=pdf. The Dear Colleague Letter is a "significant guidance document." Id . at n.1 (citing Agency Good Guidance Practices, 72 Fed. Reg. 3432-40 (Jan. 25, 2007)). 54 (2013).

${ }^{28}$ Violence Against Women Reactivation Act of 2013, Pub. L. No. 113-4, 127 Stat.

${ }^{29}$ The Act is discussed in more detail infra notes $32-42$ and accompanying text.

${ }^{30}$ For example, President George H.W. Bush signed the Federal Campus Sexual Assault Victim's Bill of Rights, amending the Clery Act, in 1992. The Federal Campus Sexual Assault Victims' Bill of Rights, CLERY CTR. FOR SEC. ON CAMPUS, http://clerycen ter.org/federal-campussexual-assault-victims\%E2\%80\%99-billrights, archived at http:// perma.cc/J5D3-QTH5. The law defined rights, including that "survivors shall be notified of their options to notify law enforcement"; the "accuser and accused must have the same opportunity to have others present"; "both parties shall be informed of the outcome of any disciplinary proceeding"; "survivors shall be notified of counseling services"; and "survivors shall be notified of options for changing academic and living situations." Id.

${ }^{31}$ Office of the Press Secretary, Fact Sheet: Not Alone-Protecting Students from Sexual Assault, ThE WHITE HouSE (Apr. 29, 2014), hitps://www.whitehouse.gov/thepress-office/2014/04/29/fact-sheet-not-alone-protecting-students-sexual-assault, archived at https://perma.cc/PB7P-NP9T. 
Funds furnished through the Violence Against Women Act have served as a major source of efforts to improve campuses' response to helping victims. Originally enacted in 1994, VAWA was the first comprehensive attempt by Congress to address domestic violence and sexual assault $t^{32}$ and "forms the backbone" of the nation's response to them..$^{33}$ The Act has provided millions of dollars in grants to increase prosecution of violent crimes against women. ${ }^{34}$ Since its inception, VAWA has improved the nation's response to domestic violence, sexual assault, dating violence, and stalking, and the act provides for grants to states in order to improve law enforcement's response to violence against women and to encourage a coordinated community response to domestic violence and sexual assault. ${ }^{35}$ VAWA also authorized a commission to evaluate increasing the penalties for rape tried in federal court. ${ }^{36}$ VAWA was reauthorized in 2000 as part of the Victims of Trafficking and Violence Protection Act. ${ }^{37}$ It was reauthorized again in 2005, creating the Sexual Assault Services Program-the first federal funding source dedicated to direct services for victims of sexual assault. ${ }^{38}$ Most recently, the 2013 reauthorization of VAWA includes additional funding for

${ }^{32}$ WeIsBerg, supra note 2 , at 530.

${ }^{33}$ The White House Council on Women \& Girls, Rape and Sexual Assault: A Renewed CALl to ACtion 3 (2014), available at http://www.whitehouse.gov/sites/de fault/files/docs/sexual_assault_report_1-2l-14.pdf.

${ }^{34}$ VAWA provides federal grants to state, local, and tribal law enforcement authorities to investigate and prosecute violent crimes against women. See, e.g., 42 U.S.C. $\S 3796 \mathrm{gg}$ (2012) (Services, Training, Officers, and Prosecutors Grant Program or "STOP" Grants); 42 U.S.C. § 3796hh (2012) (Grants to Encourage Arrest Policies and Enforcement Protection Orders); Albert R. Roberts, Myths, Facts, and Realities Regarding Battered Women and Their Children: An Overview, in HANDBook Or. DomEsTiC Vrolence Intervention Strategies: Policies, Programs, and Legal Remedies 3, 19 (Albert R. Roberts ed., 2002). From 2010 to 2013, Congress authorized over $\$ 600$ million for the STOP Grant Program and $\$ 150$ million for the Grants to Encourage Arrest Policies and Enforcement of Protection Orders. See Lisa N. Sacco, Cong. Research Serv., R42499, The Violence Against Women Act: Overview, Legislation, and Federal FUNDING 19, 27 (2014).

35 Nat'l Network to End Domestic Violence, The Violence Against Women Reauthorization Act of 2013: Safely and EFrectively Meeting the Needs of More VICTIMS 2, archived at http://perma.cc/9S9W-ZFUR [hereinafter NAT'L NETWORK, VAWA REAUTHORIZATION ACT].

${ }^{36}$ See Violent Crime Control and Law Enforcement Act of 1994, Pub. L. No. 103322, $\S \S 40111-40112,108$ Stat. 1796 (1994) (codified as amended at 18 U.S.C. $\S 2247$ and 28 U.S.C. $\$ 994)$; see also White House, FActsheet: The Violence Agninst WoMEN ACT 1 (2014), archived at http://perma.cc/H28D-TVVQ ("VAWA has improved the criminal justice response to violence against women by: holding rapists accountable for their crimes by strengthening federal penalties for repeat sex offenders and creating a federal 'rape shield law'....").

${ }^{37}$ Victims of Trafficking and Violence Protection Act of 2000, $\S 1$ 1001-1603, Pub. L. No. 106-386, 114 Stat. 1464 (2000).

${ }^{38}$ Nat'l Network to End Domestic Violence, The Violence Against Women ACT of 2005: Summary Or Provisions 2, archived at hitp://perma.cc/ADE2-7RNM. 
sexual assault response teams ${ }^{39}$ and funding for Sexual Assault Nurse Examiners (SANE) ${ }^{40}$

Federal law has also specifically addressed sexual violence on campus. The 2013 reauthorization of VAWA included millions of dollars for domestic violence programs, ${ }^{41}$ including "train[ing] all campus law enforcement to respond effectively to domestic violence, dating violence, sexual assault and stalking." 42 Additionally, the Campus SaVE Act, which amends the Jeanne Clery Act ${ }^{43}$ expanded the duties of universities ${ }^{44}$ to maintain a public record of sexual offenses and other campus crimes. ${ }^{45}$ The Campus SaVE Act requires colleges and universities to implement a recording process for incidents of dating violence, as well as to formally report crimes that occur on public property near college campuses. In addition, schools are required to create plans to prevent sexual violence and to educate victims on existing advocacy, legal assistance, and mental health programs. ${ }^{46}$ Federal funds through the Grants to Reduce Domestic Violence, Dating Violence, Sexual

${ }^{39}$ Violence Against Women Reauthorization Act of 2013, § 101(2)(M), Pub. L. No. 113-4, 127 Stat. 54 (2013) (codified at 42 U.S.C. $\$ 3796 \mathrm{gg}(\mathrm{b})(15)$ ).

${ }^{40}$ See id. at $\S 102(\mathrm{a})(1)(\mathrm{A})(\mathrm{ix})$ (codified at 42 U.S.C. $\$ 3796 \mathrm{hh}(\mathrm{b})(17)$ ).

${ }^{41}$ New Violence Against Women Act Includes Historic Protections for Native Americans and LGBT Survivors, DemOCRACY NOW! (Mar. 8, 2013), http://www.democracynow.org/2013/3/8/new_violence_against_women_act_includes, archived at http://perma $. c \mathrm{~s} / 5 \mathrm{~F} 5 \mathrm{H}-348 \mathrm{P}$.

${ }_{42} I d$. at $\S 303(4)(B)$ (codified at 42 U.S.C. $\S 14045 b(d)(3)(C)$ ).

${ }^{43}$ Campus SaVE is section 304 of the 2013 Reauthorization of the Violence Against Women Act. See id. at $\$ 304$. Campus SaVE updates the Clery Act to address the current national trend of the "highest rates of stalking and intimate partner violence as well as high rates of rape and attempted rape." It includes sections on transparency of campus crime statistics, including providing a written copy of their rights to victims and provides accountability through minimum standards for disciplinary procedures, educational programs, and partnerships with the U.S. Department of Justice. See The Campus Sexual Violence Elimination (SaVE) Act, Clery CTR. FOR SEC. on Campus, http://clerycenter .org/campus-sexual-violence-elimination-save-act, archived at http://perma.cc/PS32AT82.

${ }^{44}$ VAWA Reauthorization, CleRY CTR. FOR SEC. ON CAMPUS, http://clerycenter.org/ article/vawareauthorization, archived at http://perma.cc/RF9E-C2VM (noting that these provisions apply to all post-secondary institutions that participate in federal financial aid programs under Title IV).

${ }_{45}$ The 1990 Jeanne Clery Disclosure of Campus Security Policy and Campus Crimes Statistics Act requires colleges and universities that participate in federal financial aid and work study programs to keep information about campus and near-campus crimes. See Jeanne Clery Disclosure of Campus Security Policy and Campus Crime Statistics Act, 20 U.S.C. \$ 1092(f)(1) (2012) (stating the Act applies to "[e]ach eligible institution participating in any program under this subchapter and part $C$ of subchapter I of chapter 34 of title 42"); 42 U.S.C. $\$ \$ 2751-57$ (Chapter 34, Subchapter 1, Part C) (describing federal work-study programs); see also The Campus Sexual Violence Elimination (SaVE) Act, supra note 43 (describing the requirements of SaVE for campuses, including disclosing incidents of domestic violence, dating violence, sexual assault, and stalking in an annual campus crime statistic report). For additional discussion of the Clery Act, see supra notes 16-25 and accompanying text.

${ }^{46}$ See Nat'l Network, VAWA Reauthorization Act, supra note 35, at 1; The Campus Sexual Violence Elimination Act, JEANnE CleRY ACt INFo., http://www.cleryact info/campus-save-act.html, archived at http://perma.cc/9K6L-GRYT. 
Assault, and Stalking on Campus Program (also funded through VAWA ${ }^{47}$ ) have "significantly expanded" universities' ability to adopt a comprehensive response to these crimes. ${ }^{48}$

Redress for a school's improper response to sexual assault can be derived from federal legislation under Title IX of the Education Amendments of $1972 .{ }^{49}$ Title IX was ground-breaking civil rights legislation that banned sex discrimination in schools that receive federal funding..$^{50}$ It states that "[n]o person in the United States shall, on the basis of sex, be excluded from participation in, be denied the benefits of, or be subjected to discrimination under any education program or activity receiving Federal financial assistance." "5l Sexual violence-rape, sexual assault, sexual battery, and sexual coercion-are all forms of sexual harassment covered under Title IX ${ }^{52}$ because they "interfere with students' rights to receive an education free from discrimination." 53 In 2001, the Department of Education's Office of Civil Rights (OCR) published a guide explaining that when a student sexually harasses another student, the harassing conduct creates a "hostile environment" if the conduct is "sufficiently serious to deny or limit the student's ability to participate in or benefit from the school's program." ${ }^{4}$ Plaintiffs do not need to show a repetitive series of incidents to successfully prove the existence of a hostile environment, particularly if the harassment is physical in nature. ${ }^{55}$ Educational institutions have an unqualified responsibility under Title IX to take immediate and effective steps to end sexual harassment and sexual violence and to create and maintain a learning environment free of such harms and distractions. ${ }^{56}$

The OCR again issued guidelines in its "Dear Colleague Letter" in 2011 to help universities that receive federal funding navigate Title IX re-

\footnotetext{
${ }^{47}$ See Grant Programs, U.S. Disp't of Justice: Orface on Violence Against WoMEN, http://www.justice.gov/ovw/grant-programs, archived at http://perma.cc/KJA63VUT (listing the Campus Program as one of the grants funded under the Violence Against Women Act).

${ }_{48}$ Jordan, The Safety of Women, supra note 23, at 145.

49) See 20 U.S.C. $\$ \$ 1681-1688$ (2012).

so $\mathrm{ld}$. at $\$ 1681(\mathrm{a})$. The law does provide for some exceptions, including schools "controlled by a religious organization," see id. at $\$ 1681$ (a)(3) and military institutes, see id. at $\S 1681(4)$.

${ }^{51} \mathrm{Id}$. at $\$ 1681(\mathrm{a})$.

52 Dear Colleague Letrer, supra note 27 , at 1-2.

${ }^{53} \mathrm{Id}$. at 1.

${ }^{54}$ U.S. Dep't of Educ. Office for Civil Rights, Revised Sexunl Harassment Guidance: Harassment of Students by School. Employees, Other Students, or ThIRD PARTIEs 12 (2001), archived at http://perma.cc/W8BM-ZLLF [hereinafter REvised Sixual Harassment Guidance].

${ }^{55}$ See id at 6.

${ }^{56} C f$. id. at ii-iii (discussing institutions' obligations under Title IX and stating: "Preventing and remedying sexual harassment in schools is essential to ensuring a safe environment in which students can learn."); Dear Collengue LetTer, supra note 27, at 1 ("Sexual harassment of students, which includes acts of sexual violence, is a form of sex discrimination prohibited by Title IX.").
} 
quirements. ${ }^{57}$ In this letter, the OCR advises that schools make all attempts to remedy sexual harassment and sexual assault in schools as well as to take proactive measures to prevent this behavior and to work diligently to prevent its recurrence..$^{58}$ These recommendations of responsibilities of educational institutions to address student complaints of sexual assault under Title IX provide that once a school learns of a sexual assault, it must promptly take a number of steps to investigate the incident, help the victim, and remedy the issue. ${ }^{59}$ While a complaint is being investigated, institutions are encouraged to offer some remedies to victims proactively, such as offering services to protect the victim from the alleged offender. ${ }^{60}$ Schools must also use a preponderance of the evidence standard to resolve complaints and offer equal opportunities for both parties to present evidence and witnesses on their behalf. ${ }^{61}$

Under Title IX, higher learning institutions can be held legally responsible for monetary damages if a student suffers harassment (including sexual assault) ${ }^{62}$ committed by staff, faculty, or another student, and the school had authority over both the perpetrator and the environment in which the harassment took place. ${ }^{63}$ Title IX claims may also be raised based on the existence of "a hostile educational environment." ${ }^{64}$ As a threshold matter, plaintiffs must show that that they subjectively perceived the environment to be hostile or abusive. ${ }^{65}$ In addition, they must demonstrate that the environment objectively was hostile or abusive; this condition is met if the environment was "permeated with discriminatory intimidation, ridicule, and insult sufficiently severe or pervasive to alter the condition" of the educational environment. ${ }^{66}$ Courts have found liability in instances when the school's response to the harassment was "clearly unreasonable" in light of known circumstances; ${ }^{67}$ when sufficient evidence demonstrated that a university acted with "deliberate indifference" to the sexual harassment of which the university

${ }^{57}$ Dear Colleague Letter, supra note 27, at 2.

${ }^{58}$ See id.

${ }^{59}$ See id. at 3-14.

${ }^{60}$ See id. at 16-17.

${ }^{61}$ See id. at 11.

${ }^{62}$ Id. at 1 ("Sexual harassment of students, which includes acts of sexual violence, is a form of sex discrimination prohibited by Title IX.").

${ }^{63}$ See Davis ex rel. LaShonda D. v. Monroe Cnty. Bd. of Educ., 526 U.S. 629, 644-45 (1999) (stating that liability is limited "to circumstances wherein the [institution] exercises substantial control over both the harasser and the context in which the known harassment occurs"); Franklin v. Gwinnett Cnty. Pub. Sch., 503 U.S. 60, 76 (1992) ("[W]e conclude that a damages remedy is available for an action brought to enforce Title IX."); Cannon v. Univ. of Chi., 441 U.S. 677, 717 (1979) (holding that Title IX is enforceable through an implied right of action).

${ }_{64}^{64}$ See Hayut v. State Univ. of N.Y., 352 F.3d 733, 750 (2d Cir. 2003). 2011).

${ }^{65}$ See Papelino v. Albany Coll. of Pharmacy of Union Univ., 633 F.3d 81, 89 (2d Cir.

${ }_{60}^{6}$ See id. (citations omitted).

${ }^{67}$ Davis, 526 U.S. at 630. 
has actual knowledge; 68 and when the harassment was "so severe, pervasive, and objectively offensive that it can be said to deprive the victims access to the educational opportunities or benefits provided by the school." 69 Even a single sexual assault by a student on a peer can be sufficient to create and sustain a hostile environment claim under Title IX. ${ }^{70}$

\section{The Problem of Underreporting}

The federal government's efforts to curb sexual assault on campus, though substantial, suffer from an inherent limitation. For despite the disturbingly common incidence of the crime, rape is also the most underreported of all violent crimes. ${ }^{71}$ At colleges, victims often do not make formal reports of the crime to police; estimates of formal reports range only from $5 \%$ to $33 \% .{ }^{72}$ Both on campuses and in society at large, victims more frequently disclose the violence to informal support systems such as family and friends. ${ }^{73}$ Much research has revealed the importance of a supportive reaction by those who receive the victim's disclosure. ${ }^{74}$ In particular, supportive responses by the recipient of the disclosure increase the victim's likelihood of seeking assistance. ${ }^{75}$ This dynamic is crucial because the damage inflicted by rape does not end with the act itself. Rather, it is common for victims to experience a wide range of significant physical and emotional traumas from the crime: flashbacks, posttraumatic stress, depression, anxiety, sleep disorders, eating disorders, and other negative and persisting consequences. ${ }^{76} \mathrm{Re}-$

${ }^{68}$ See Simpson v. Univ. of Colo. Boulder, 500 F.3d 1170, 1176-78 (10th Cir. 2007).

${ }^{69}$ Davis, 526 U.S. at 650.

${ }^{70}$ See S.S. v. Alexander, 177 P.3d 724, 742-43 (Wash. Ct. App. 2008); see also Brown v. Hot, Sexy \& Safer Prods., Inc., 68 F.3d 525, 541 n. 13 (1st Cir. 1995) (noting that a "one-time episode is [not] per se incapable of sustaining a hostile environment claim").

${ }^{71}$ W. David Allen, The Reporting and Underreporting of Rape, 73 S. EcoN, J. 623, 623 (2007).

${ }^{72}$ Lisa A. Paul et al., College Women's Experiences with Rape Disclosure: A National Study, 19 Violence Agninst Women 486, 487 (2013).

${ }^{73}$ See, e.g., Christopher P. Kriebs et al., The Campus Sexual Assault (CSA) STUDY 5-21 (2007), available at https://www.ncjrs.gov/pdffiles I/nij/grants/221153.pdf; Courtney E. Ahrens et al., Deciding Whom to Tell: Expectations and Outcomes of Rape Survivors' First Disclosures, 31 Psychol. Women Q. 38, 38 (2007); Bonnie S. Fisher et al., Reporting Sexual Victimization to the Police and Others: Results from a NationalLevel Study of College Women, 30 Crim. Just. BeHAv. 6, 13-14 (2003); Sarah E. Ullman \& Henrietta H. Filipas, Correlates of Formal and Informal Support Seeking in Sexual Assault Victims, 16 J. INTER PERSONAL VIOLENCE 1028, 1029 (2001).

${ }^{74}$ See Ullman \& Filipas, supra note 73 , at 1029.

${ }^{75}$ See Paul et al., supra note 72, at 487; Ullman \& Filipas, supra note 73, at 1029.

${ }^{76}$ See Effects of Sexual Assault, RAPE, ABuse \& INCEST NAT'L NETwORK, https:// www.rainn.org/getinformation/effects-of-sexual-assault, archived at https://perma.cc/N9 CW-5WD2. 
searchers have described the psychological condition often resulting from the profound suffering of victims as Rape Trauma Syndrome. ${ }^{77}$

That the overall rate of reporting sexual assault has not significantly increased since the $1990 \mathrm{~s}^{78}$ reflects a critical deficiency in the justice system's efforts to reduce this crime. Formal reporting to law enforcement authorities, both on and off campus, despite its relatively infrequent nature, is crucial "input" into the system for several reasons. First, reporting is the only way in which an individual victim can pursue legal action against a perpetrator. If the perpetrator will ever be held accountable for the crime, it will likely only be through the external criminal justice system; thus, reporting the crime is an essential first step in preventing others like it. ${ }^{79}$ Second, in a global sense, victim reporting increases the probability that authorities will detect perpetrators. Conversely, not reporting reduces the probability of detection; accordingly, officials are prevented from gaining essential information to apprehend offenders. ${ }^{80}$ Under this economic model of crime in which a victim possesses a scarce resource-information about a rape-that she can give up only at significant cost to herself, ${ }^{81}$ underreporting weakens the link between crime and perpetrator accountability. ${ }^{82}$ Finally, reporting the crime links victims to resources that can be vital to the healing process. ${ }^{83}$ Unreported sexual assault, on the other hand, "eliminates the possibility that an offender will be arrested or convicted." 84 If those who sexually assault women perceive the likelihood of apprehension from authorities to be low, this calculation can undermine any deterrent value the legal system has in

${ }^{77}$ See, e.g., Ann Wolbert Burgess \& Lynda Lytle Holmstrom, Rape Trauma Syndrome, 131 Ам. J. Psychintry 981, 982 (1974).

${ }^{78}$ See Kate B. Wolitzky-Taylor et al., Is Reporting of Rape on the Rise? A Comparison of Women With Reported Versus Unreported Rape Experiences in the National Women's Study-Replication, 26 J. INTERPERSONAL VIOLENCE 807, 821 (2011).

${ }^{79}$ See Allen, supra note 71 , at 623 ("Reporting by victims reinforces the possibility of detection and the expected cost of illegal activity; these elements are critical to establishing a disincentive for individuals to commit crime.").

${ }^{80}$ See id.

${ }^{81}$ See id. at 624.

${ }^{82}$ See Lynn Langton et al., U.S. Dep't of Justice, Victimizations Not RePORTED TO THE POL.JCE, 2006-2010 1 (2012), archived at http://perma.cc/YEQ6-SN3X ("When crimes are not reported to the police, victims may not be able to obtain necessary services to cope with the victimization, offenders may go unpunished, and law enforcement and community resources may be misallocated due to a lack of accurate information about local crime problems.").

${ }^{83}$ See Allen, supra note 71 , at 625 ("Social support can emanate from private sources ... and from public sources ... but only if the victim reveals information about the crime."); The Effects of Sexual Assault and Rape, JoYFul. HE^rT Found., http://www .joyfulheartfoundation.org/learn/sexual-assault-rape/effectssexual-assault-and-rape,

archived at http://perma.cc/47WK-6W23 ("[E]ach person will heal according to his or her own methods and own time. Know that no one is alone in their healing process and that there are resources for those who want to seek them out and begin on the restorative pathway to healing.").

${ }^{84}$ Ronet Bachman, The Factors Related to Rape Reporting Behavior and Arrest: New Evidence from the National Crime Victimization Survey, 25 Crim. Just. \& BeHav. 8, 9 (1998). 
preventing the crime. ${ }^{85}$ With respect to sexual assault on campus, the model has a very practical application because very few sexual assaults on campus are reported. ${ }^{86}$ In addition, the common assumption that men who commit sexual assault in college make a single bad decision is erroneous. ${ }^{87}$ Instead, repeat predators may account for as many as nine out of every ten rapes. ${ }^{88}$ Thus, the benefits of reporting are not limited to the individual victim who seeks justice and may experience the salutary effects of knowing that her perpetrator has been punished for his crime against her. ${ }^{89}$ More broadly, increased reporting can eventually create an environment in which serial perpetrators have a disincentive to commit the crime-their fear of getting caught. ${ }^{90}$ Individual victims possess crucial information about perpetrators, and the reporting of sexual assault to police can have the very real consequence of deterring future crime against other women. As the Rape, Abuse, and Incest National Network's website informs victims: "Reporting to the police is the key to preventing sexual assault: every time we lock up a rapist, we're preventing him or her from committing another attack. It's the most effective tool that exists to prevent future rapes."

Moreover, university administrators have an important role in holding perpetrators accountable and can take action by suspending or expelling perpetrators ${ }^{92}$ or taking protective steps such as helping the victim transfer out of classes she shares with the perpetrator. ${ }^{93}$ When they do not hold a perpe-

$85 \mathrm{ld}$

${ }^{86}$ See Sofi Sinozich \& Lynn Langton, U.S. Dep't of Justice, Rape and Sexual. Assault Victimization Among College-Age Females, 1995-2013 1, 9 (2014), archived at hitp://perma.cc/28AX-Q62X.

${ }^{87}$ See Joseph Shapiro, Myths That Make It Hard to Stop Campus Rape, Nat'L PuB. RAdio (Mar. 4, 2010), http://www.npr.org/templates/story/story.php?storyId=1242721 57, archived at http://perma.cc/PV5Z-6E7W.

${ }^{88}$ Shapiro, supra note 87; see also Jennifer Peebles \& Kristen Lombardi, 'Undetected Rapists' on Campus: A Troubling Plague of Repeat Offenders, CTR. For PUB. INTEGRITY (May 19, 2014), http://www.publicintegrity.org/2010/02/26/4404/undetected-rapists-cam pus-troubling-plague-repeat-offenders, archived at http://perma.cc/C22C-Y7XZ (discussing study of serial rape at several colleges finding that $91 \%$ of rapists were serial rapists in a research study). For further discussion and statistics regarding repeat offenders, see generally David Lisak \& Paul M. Miller, Repeat Rape and Multiple Offending Among Undetected Rapists, 17 VIOLENCE \& ViCTIMS 73 (2002).

${ }^{89}$ See Reporting Rape and Sexual Assault, AFTER SILENCE, http://www.aftersilence .org/reporting-rape.php, archived at http://perma.cc/BW5C-SUPH (explaining that "rape victims can feel a sense of closure when a rapist is brought to justice and convicted accordingly").

${ }^{90}$ See Allen, supra note 71 , at 623.

${ }^{91}$ Reporting the Crime to the Police, RAPE, Abuse \& InCESt NAt'L Network, https:/ /rainn.org/get-information/legal-information, archived at hitps://perma.cc/PX32-8ZAZ.

${ }^{92}$ See Tyler Kingkade, Fewer Than One-Third of Campus Sexual Assault Cases Result in Expulsion, Huffington Post (Sept. 28, 2014), http://www.huffingtonpost.com/ 2014/09/29/campus-sexual-assault_n_5888742.html, archived at http://perma.cc/54CKZDW3.

${ }^{93}$ Sexual Misconduct - Confidentiality, Privacy, and Reporting Policy, Barry UNiv., https://www.barry.edu/student-handbook/handbook/sexual-misconduct-reporting.html, archived at https://perma.cc/A3L9-NXNB (listing a variety of actions that administrators can take to protect and accommodate victims). 
trator accountable for his actions, those administrators have perpetuated risky and harmful attitudes of campus sexual assault ${ }^{94}$ The resulting ability to commit sexual assault with impunity seems likely both to embolden potential assailants and to discourage victims from disclosing or reporting sexual assault.

\section{The Impact of Women Officers on Sexual Assault Reporting}

Rather than stemming from a single source, the underreporting of sexual assault can be ascribed to a number of causes..$^{95}$ Research suggests that a low proportion of female police officers is one factor contributing to the reluctance of rape victims to come forward. For several reasons, greater numbers of women working in police agencies has been found to encourage more reporting by victims. ${ }^{96}$ The potential benefit from bolstering the presence of women in police forces takes on heightened focus on college campuses, where nationally women comprise a decided majority of the student population. ${ }^{97}$

Although the number of assaults and the degree of statistical underrepresentation of sexual assault in the United States have proven challenging to calculate with precision, ${ }^{98}$ they are undoubtedly large. A majority of victims do not report this crime to police..$^{99}$ Victims' reporting behavior has very real implications because reporting sexual assault to law enforcement is a necessary condition for any police response to, perpetrator accountability for, and future prevention of the crime..$^{100}$

The willingness to report can be hindered by several factors. Victims are often embarrassed and ashamed; as a result, they may not want anyone to learn of their assault. ${ }^{101}$ Some may not understand the definition of rape or

${ }^{94}$ See Peter Finn, The Higher Educ. Ctr. for Alcohol, and Other Drug Prevention, Preventing Alcohol-Rel 1 ted Problems on Campus: Acquaintance Rape, A Guide for Program Coordinators, 5 (1997), available at http://www.popcen ter.org/problems/rape/PDFs/acqrape.pdf (saying that these myths include "that drinking and sex go together, that forcing a woman to have sex is acceptable, and that the school does not care about the problem").

${ }^{95}$ See infra notes 101-04 and accompanying text.

${ }^{96}$ See infra notes $149-54$ and accompanying text.

${ }^{97}$ See Mark Hugo Lopez \& Ana Gonzalez-Barrera, Women College Enrollment Gains Leave Men Behind, PEw ResearCH CTR. (Mar. 6, 2012), http://www.pewresearch .org/fact-tank/2014/03/06/womens-college-enrollment-gains-leave-men-behind/, archived at http://perma.cc/N9RK-YFWJ.

${ }_{98}$ Yung, supra note 8 , at 1.

99 See Jennifier L. Truman \& Lynn Langton, U.S. Dep't of Justice, Criminal. VICTIMIZATION, 20138 (rev. 2014), archived at http://perma.cc/4JUJ-LM5H; Rape in the United States: The Chronic Failure to Report and Investigate Rape Cases: Hearing Before the Subcomm. on Crime and Drugs of the S. Comm. on the Judiciary, 111 th Cong. 27-28 (2010), available at http://www.gpo.gov/fdsys/pkg/CHRG-111shrg64687/pdf/CH RG-111 shrg64687.pdf.

${ }^{100}$ Bachman, supra note 84 , at 9.

${ }^{101}$ See Fischer et al., supra note 73, at 32 (inferring from study that some sexual assault victims believe that "a sexual victimization was something sufficiently embar- 
are afraid of police reaction. ${ }^{102}$ The fear of police reaction to a report of rape often involves a victim's fear that she will be treated by police with "victimblaming attitudes, behaviors, and practices." 103 This fear is not unfounded; the reporting process includes risk to victims, and if a victim experiences harsh treatment from law enforcement when attempting to file a report, she may also experience secondary traumatization. ${ }^{104}$

Victims of sexual assault have complained that police officers have responded to their rape complaints with inappropriate reactions ranging from indifference to skepticism to hostility. When one victim could not describe her assailant in detail, the officer asked, "You don't even remember the color of his eyes?"105 Another officer told a woman, "For every single rape I've had, I've had 20 that are total bullshit." 106 Other police comments about which victims have complained include: "You can't be raped by someone you've dated," 107 and women should not "go out, get drunk and expect not to get raped." 108 One woman reported that a detective in her case informed her that because " "no one had a limb cut off and there was no video of the incident,' prosecutors 'wouldn't see this [the rape] as anything more than a girl getting drunk at a party." 109 A student also stated that a school police officer told her, "women need to stop spreading their legs like peanut butter or rape is going to keep on happening "til the cows come home," 110 while

rassing or shameful that it should even be kept from their families"); Gray, Why Victims Don't Report, supra note 15; see also Bachman, supra note 84, at 21 (finding that a major reason for victims not reporting rape to the police was that they considered it to be a "private matter").

${ }_{102}$ Gray, Why Victims Don't Report, supra note 15.

${ }^{103}$ Rebecca Campbell et al., Preventing the "Second Rape": Rape Survivors' Experiences With Community Service Providers, 16 J. InTERPIRSONAL VIOLENCE 1239, 1240 (2001); see also The White House Council on Women \& Girls, Rape and Sexual. Assaul., supra note 33, at 17 ("Some victims report that law enforcement officers actively discouraged them from reporting, asked questions about their sexual history and dress, and overemphasized prosecution for false reports.").

104 See Karen Rich \& Patrick Seffrin, Police Interviews of Sexual Assault Reporters:

Do Attitudes Matter?, 27 Violence \& Victims 263, 265 (2012) ([R]eporters [of rape] are still at risk for revictimization.").

${ }^{105}$ Claire Gordon, Why College Rape Victims Don't Go to the Police, Al. JAzEERA AMEriCA (May 19, 2014), http://america.aljazeera.com/watch/shows/america-tonight/articles/2014/5/19/why-college-rapevictimsdonatgotothepolice.html, archived at http:// perma.cc/9Q42-SRT4.

${ }^{106} \mathrm{ld}$.

${ }^{107}$ Naomi Martin, For Rape Victims, Hurt and Anger in Dealing with New Orleans Police, NOLA (Nov. 15, 2014), http://www.nola.com/crime/index.ssf/2014/11/ new_orleans_police_ignore_sex.html, archived at http://perma.cc/4L5N-37TT.

${ }^{108}$ Tyler Kingkade, USC Student: Police Said I Wasn't Raped Because He Didn't Orgasm, HufFInGTON Post (July 22, 2013), http://www.huffingtonpost.com/2013/07/22/ usc-rape-investigation_n_3607954.html?utm_hp_ref $=\mathrm{tw}$, archived at http://perma.cc/ W3LM-JWDT [hereinafter Kingkade, USC Student].

${ }^{109}$ Kate Dries, Montana Attorneys Said 'Terrible Things' to Rape Victims: DOJ Report, JEzEBEL (Feb. 17, 2014) (alteration in original), http://jezebel.com/montanaattorneys-said-terrible-things-to-rape-victim-1524327069, archived at hitp://perma.cc/ W3SG-3SDB.

${ }_{110}$ Tyler Kingkade, Why It Really Matters When College Officials Say Terrible Things About Rape, Huffington Post (Nov. 20, 2014), http://www.huffingtonpost.com/2014/ 
another complained of a police determination that no rape had occurred because the assailant did not orgasm. ${ }^{111}$ Sexual assault victims described to Human Rights Watch insensitive and egregious treatment by police officers who reportedly questioned their credibility and minimized their allegations. ${ }^{112}$ One woman said, "they just didn't listen to me, they made me feel completely ashamed of myself, they made me feel like I was lying or like I was too stupid to understand what happened to me, that I was trying to make something a big deal that wasn't that big of a deal."113

The phenomenon of sexual assault is characterized by a striking incongruity between the gender of victims and that of law enforcement personnel charged with their protection. The crime of sexual assault disproportionately affects women. ${ }^{114}$ At the same time, law enforcement personnel assigned to play a "central role" in addressing campus sexual assault"15 are overwhelmingly men. Statistics from the U.S. Department of Justice reveal that women continue to be underrepresented in campus law enforcement positions. ${ }^{116}$ Only about $17 \%$ of sworn officers at colleges and universities are women; ${ }^{117}$ even that number represents an increase from a 1990 study that showed male officers outnumbering females $90 \%$ to $10 \%$ on large midwestern and southeastern residential campuses. ${ }^{118}$ Much of the paucity of women officersboth generally and on campus - can be ascribed to the simple fact that law enforcement agencies have historically been dominated by men. ${ }^{119} \mathrm{~A}$ signifi-

11/18/college-officials-rape-things-they-say_n_6173254.html, archived at http://perma .cc/HK4V-2FBL.

${ }^{11}$ See Kingkade, USC Student, supra note 108.

112 See US: DC Police Mishandle Sexual Assault Cases, Human Rts. Wлtch (Jan. 24, 2013), http://www.hrw.org/news/2013/01/24/us-dc-police-mishandle-sexual-assaultcases\#stories, archived at http://perma.cc/E5KV-T7QH.

${ }^{113} \mathrm{Id}$.

114 See Weisberg, supra note 2 . We do not minimize the impact of rape on male victims. According to the Campus Sexual Assault Study, $6.1 \%$ of men were victims of attempted or completed sexual assault in college. KREBS ET AL., supra note 73, at 5-5.

${ }^{115}$ Office of the Press Secretary, Fact Sheet, supra note 31.

${ }^{116}$ Many campuses also employ women in non-sworn positions, but these employees, who do not have the power of arrest, are not the subject of this article. See BRIAN A. Reaves, U.S. Dep't. of Justice, Bureau of Justice Statistics: Campus Law EnFORCEMENT, 2004-05 1 (2008), archived at http://perma.cc/VBX8-XWJE.

${ }^{117} \mathrm{Id}$. at 5 (finding also that $31 \%$ of sworn campus officers were of a racial or ethnic minority).

118 John J. Sloan, The Modern Campus Police: An Analysis of Their Evolution, Structure and Function, 11 AM. J. Police 85, 96, 102 (1992) (studying large, residential campuses in the Midwest and Southeast, including Auburn University, University of Florida, State University of Kentucky, University of Mississippi, Vanderbilt, Indiana University, Michigan State University, Ohio State, and Northwestern); see also SusAn Ehri.ICH Martin \& Nancy C. Jurik, Doing Justice, Doing Gender: Women in Legal. and Criminal Justice OcCupations 51 (2007) ("Before the 1970s, nearly all police officers in the United States were white men; women comprised less than 2 percent of sworn personnel, and 'policewomen' served in specialized positions.").

${ }^{119}$ See Philip E. Carlan et al., Officer Preferences for Male Backup: The Influence of Gender and Police Partnering, 26 J. Police \& Crim. PsychOL. 4, 5 (2011) "The longstanding and engrained hostilities of policemen toward policewomen have been elsewhere well-documented. It has been suggested that male officers construct barriers to 
cant increase in female police began only with the enactment of legislation prohibiting discrimination in employment on the basis of sex. ${ }^{120}$

This sharp imbalance in the composition of police forces is magnified on college campuses by the disproportionate representation of women. ${ }^{121}$ While in 1947 male students outnumbered female students by more than two to one, ${ }^{122}$ women's increased enrollment has reversed that gender gap on campus steadily ever since. ${ }^{123}$ Today, more than half of students on college campuses are women: public universities have a male-female ratio of about 43.6 to $56.4 \%,{ }^{124}$ and private institutions tend to have even a larger percentage of women, about $40.7 \%$ to $59.3 \%$. $^{125}$ Studies on the widening gender gap in college attendance have produced multiple theories for the phenomenon: for example, the rising age of first marriages for women; the increases in girls' expected economic returns from college attendance; ${ }^{126}$ the presence of

keep women in subordinate roles as a means to protect the masculine integrity of police organizations." (citations omitted)); $c f$. KIM Lonsway ET AL., NAT'L CTR. For WOMEN \& Policing, Feminist Majority Found., Hiring \& Retainingi More Women: The Advantages to Law ENFORCEMENT AgenCIES 2 (2003), archived at http://perma.cc/PSH3WMR7 ("In 1968, the Indianapolis Police Department made history by assigning the first two female officers to patrol on an equal basis with their male colleagues. Since that time, women have entered the field of law enforcement in increasing numbers and played a critical role in the development of modern policing. Yet the number of women in law enforcement has remained small and the pace of increase slow."); MARTIN \& JURIK, supra note 118 , at $77-82$ (discussing how hiring and training create inequality between male and female police officers).

${ }^{120}$ See Amalia R. Miller \& Carmit Segal, Do Female Officers Improve Law Enforcement Quality? I (Sept. 16, 2014) (unpublished manuscript), available at http://papers.ssrn .com/sol3/papers.cfm?abstract_id=2335990; MARTIN \& JURIK, supra note 118, at 55-60. For an example of a lawsuit brought under these discrimination laws, see United States v. City of Chi., 485 F. Supp. 543, 554 (N.D. Ill. 1974) (finding that barring females from a certain type of examination that would determine eligibility for employment and placement constituted improper discrimination against women). A more recent example is Lewallen v. City of Beaumont, 394 F. App'x 38, 44 (5th Cir. 2010) (finding that Plaintiff successfully provided evidence to show that the City had a practice of sex discrimination in its hiring procedures and that such discrimination was imbedded in the Department's hiring practices).

${ }_{121}$ See Lopez \& Gonzalez-Barrera, supra note 97 ("By 2012, the share of young women enrolled in college immediately after high school had increased to $71 \%$, but it remained unchanged for young men at $61 \%$.").

${ }^{122}$ David R. Francis, Why Do Women Outnumber Men in College?, NAt'L Bureau ECON, http://www.nber.org/digest/jan07/w12139.html, archived at http://perma.cc/8BLYLYMP.

${ }_{123}$ See, e.g., At Colleges, Women Are Leaving Men in the Dust, N.Y. Times, July 9 , 2006, at A1, archived at http://perma.cc/72NP-7UQE (stating that men made up only $42 \%$ of the nation's college students); Lopez \& Gonzalez-Barrera, supra note 97.

${ }^{124}$ Daniel Borzelleca, The Male-Female Ratio in College, Forbes (Feb. 16, 2012), http://www.forbes.com/sites/ccap/2012/02/16/the-male-female-ratio-in-college/, archived at http://perma.cc/J9DU-D5Q3 (citations omitted).

${ }_{125}$ Id.

${ }^{126}$ Claudia Goldin et al., The Homecoming of American College Women: The Reversal of the College Gender Gap, 20 J. Econ. Persp. 133, 134 (2006). 
more men in the military;:127 and even boys' higher incidence of "non-cognitive," negative behavior creating barriers to college admission. ${ }^{128}$

The presence of overwhelmingly male police forces at predominantly female universities is especially striking in light of studies showing that female officers make distinctive contributions to police culture. In general, according to the National Center for Women and Policing, women officers display better communication skills, use less excessive force, and receive fewer citizen complaints. ${ }^{129}$ Some campus law enforcement leaders recognize the special contributions that women officers can make. The police chief of Kent State University told reporters that having both men and women on the force was important, and that women "generally are better at oral and written communication." 130 Kent State officer Nancy Shefchuk, a member of the Kent State force for two-and-a-half years, said the public views female officers differently: "The public perceives females as kinder and gentler. This ... makes [the public] more willing to talk." 131

Most notably, research indicates that women officers may respond more effectively to incidents of violence against women, a crime that represents approximately half of all violent crime calls to police. ${ }^{132}$ Researchers studying the impact of female police officers who investigate gender-based crimes have found that women can be especially effective when working with those victims. ${ }^{133} \mathrm{~A}$ variety of explanations have been offered for this

${ }^{127}$ Brian A. Jacob, Where the Boys Aren't: Non-Cognitive Skills, Returns to School and the Gender Gap in Higher Education 3 (Nat'l Bureau of Econ. Research, Working Paper No. 8964, 2002), archived at http://perma.cc/Q383-K8HK.

${ }^{128} \mathrm{Id}$. at 4,18 (finding that disciplinary incidents have a substantial impact on the probability of enrolling in college, even after controlling for cognitive ability, family background, and high school achievement); see also Shannon Moon Leonetti, Letter to the Editor, Why More Black Women than Men Go to College, N.Y. Times, May 19, 1990, at $22 \mathrm{~L}$ (stating that black men may lack the father figures or mentors whose leadership would increase their chances of going to college). We have no doubt that our families and communities would benefit from having more men participate in higher education, but that issue is beyond the scope of this paper.

${ }^{129}$ LONSWAY ET AL., supra note 119, at 2; see also Christina DeJong, Gender Differences in Officer Attitude and Behavior, 15 WOMEN \& CRIM. Just. 1, 4 (2005) ("Female officers have, however, reported higher self-ratings on effective listening skills and consideration for others, while male officers report higher self-ratings on physical strength and use of physical force.").

130 Jeff Schooley, "Unique Style" Makes All Officers Valuable, DAIL Y Kent StATter, Sept. 4, 2001.

${ }^{131} \mathrm{Id}$.

132 See Lonsway et Al., supra note 119, at 8; see also Penny E. Harrington et al., Nat'l Ctr. for Women \& Policing, Feminist Majority Found., Recruiting and Retaining Women: A Self-Assessment Guide for Law Enforcement 22, archived at https://perma.cc/PR63-6G5M.

${ }^{133}$ LONSWAY ET AL., supra note 119, at 7; see also Kelley Foreman, Changing the Letters of the Law: Policewomen, $30 \mathrm{KY}$. L. ENFORCEMENT 32, 50 (" "There are a lot of things that we actually can do [because of our gender],' Spies said. 'Rape victims feel more comfortable talking to a female; we kind of display that motherly image. Sometimes we can help calm a situation more." "). One study revealed gender differences in the beliefs, biases, and responses of police officers on college campuses have towards victims of sexual assault. Male officers were more likely to view perpetrator's claim of 
finding. For example, female victims may find discussing the specific and graphic details of a violent crime more difficult when interacting with male officers. ${ }^{134}$ In addition, female victims may perceive women officers to be less inclined to be victim-blaming and to be more sensitive. ${ }^{135}$ Or it may simply be that many victims of sexual assault feel that other women will have shared experiences and common values and may be more empathetic. ${ }^{136}$ One study indicates that most male victims of sexual assault prefer to be examined by female nurses, especially in settings where female practitioners are the norm. ${ }^{137}$ Even in their choice of physicians, studies have suggested that women generally report higher satisfaction when being treated by women doctors in emergency room care. ${ }^{138}$ Thus, this preference by many women to interact with other women on issues related to women's sexual health ${ }^{139}$ is consistent with the expressed importance of the presence

innocence as credible and less likely to view the complainant as credible compared to female police officers. Regina A. Shuller \& Anna Stewart, Police Responses to Sexual Assault Complaints: The Role of Perpetrator/Complainant Intoxication, 24 L. \& Hum. BEHAv. 535, 542 (2001).

${ }^{134}$ See Cassia Spohn \& Katharine Tellis, Policing and Prosecuting Sexual Assault in los Angeles City and County: A Collaborative Study in PartnerShip with the Los Angeles Police Department, the Los Angeles County Sheriff‘s Department, and the Los Angeles County District Atrorney's Office 153, 391 , 400 (2012), available at https://www.ncjrs.gov/pdffiles1/nij/grants/237582.pdf.

${ }_{135}$ See Kenneth J. Meier \& Jill Nicholson-Crotty, Gender, Representative Bureaucracy, and Law Enforcement: The Case of Sexual Assault, 66 Pub. Admin. Rev. 850, 852 (2006) ("The fear of "victim blaming' . . . may be reduced by victim's assumption that a woman will have common values and experiences and, as a result, feel sympathetic or even empathetic to the situation."); Jan Jordan, Will Any Woman Do? Police, Gender and Rape Victims, 25 Policing: Int'L J. Police Strategies \& Mgmt. 319, 327, 329 (2002) [hereinafter Jordan, Will Any Woman Do?] "'Some women stated strongly their belief that male police officers were unlikely to be able to respond appropriately to rape complainants, since many could not differentiate between 'rape' and 'sex." ).

${ }^{136}$ Meier \& Nicholson-Crotty, supra note 135, at 852.

137 See Jo Lovett et al., Home Office Research, Sexual Assault Refirral. Centres: Developing Good Practice and Maximising Potentials 30-31, 37 (2004), archived at http://perma.cc/2CFL-86JV; see also Linda E. Ledray, Evidence Collection and Care of the Sexual Assault Survivor: The SANE-SART Response, MinNESOTA CTR. AgAinst VIOLENCE AND Abuse (2001), http://www.mincava.umn.edu/documents/commissioned/2forensicevidence/2forensicevidence.html, archived at http://perma.cc/8CEKWUVV (finding that half of female rape victims see a male examiner as extremely problematic). Even male victims often prefer to be examined by a woman because they too are most often raped by a man and experience the same generalized fear and anger towards men that female victims experience. See id.

${ }^{138}$ See Kathryn Pitkin Derose et al., Does Physician Gender Affect Satisfaction of Men and Women Visiting the Emergency Department?, 16 J. Internal Med. 218, 221 (2001).

${ }^{139}$ See Career as a Victim Advocate, CareERs in Psychology, http://careersinpsychology.org/career-as-a-victim-advocate/, archived at http://perma.cc/H342-BCEK ("Sexual assault victims, for instance, will often be more open to working with a female victim advocate than a man."). See generally Survivor Services, WomEN HelpING WoMEN, http://www.womenhelpingwomen.org/services/survivor-services/, archived at http:/ /perma.cc/4HY2-6G5Z (listing several services, offered by women to other women who have survived sexual assault, encouraging initial reporting, intervention for the immediate after-effects of assault, and ongoing support groups). 
of women to assist with both forensic nurses ${ }^{140}$ in the rape crisis setting and more generally on non-emergency women's health issues. ${ }^{141}$

When a campus has a larger number of women officers, the likelihood increases that a rape victim's first contact with the law enforcement agency will be with a female officer. Even though rape victims may prefer to be interviewed by women, ${ }^{142}$ what happens after the report is made is also crucial. ${ }^{143}$ Thus, it is essential that beyond being "comfortable," a victim must be sensitively and effectively served by a well-trained officer who does not adhere to myths about rape. ${ }^{144}$ Female officers may be less accepting of rape myths than male officers. ${ }^{145}$ Those myths include beliefs that sometimes a man cannot control himself because the victim is too sexy, that women enjoy rape, that only certain kinds of women are raped, that the victim brought on the rape by her own carelessness, that the victim lied, that the rapist did not mean to rape the victim, and that he was entitled to have sex with her. ${ }^{146}$

${ }^{140}$ See Ledray, supra note 137 (citing studies in which women expressed a strong preference for medical treatment and counseling by a woman). In one study, most victims-78.6\%, male and female-preferred Sexual Assault Referral Centre staff to be female. Rima Chowdhury-Hawkins et al., Preferred Choice of Gender of Staff Providing Care to Victims of Sexual Assault in Sexual Assault Referral Centres (SARCs), 15 J. Forensic \& LeGal MeD. 363, 363 (2008) (also finding that almost $100 \%$ of victims would continue with the examination if carried out by a female doctor, whereas $43.5 \%$ of victims said they would not if the doctor were male).

${ }^{141}$ Fiona Brooks \& David Phillips, Do Women Want Women Health Workers? Women's Views of the Primary Health Care Service, 23 J. AdvanCEd NuRsing 1207, 1207 (1996) (finding that for specific "women's health issues" gender of the health care worker is clearly important for women).

${ }^{142}$ Rich \& Seffrin, supra note 104, at 266.

${ }^{143}$ Cf. supra notes 75-76 and accompanying text.

144 See, e.g., Rich \& Seffrin, supra note 104 , at $274-75$ (stating that training and rejection of rape myths are significant predictors of interviewing skill; it is possible that a female officer with poor skills could make a rape reporter feel comfortable initially, but engage in discouraging behaviors and fail to collect good information on the crime).

${ }_{145}$ The number of studies comparing rape myth acceptance among male and female police officers has been limited. Two such studies found less rape myth acceptance among women officers. See Jennifer Brown \& Joanne King, Gender Differences in Police Officers Attitude Towards Rape; Results of an Exploratory Study, 4 Psychol. CRIME \& L. 265, 276 (1998) (finding that "policewomen in particular were unlikely to support stereotypic statements about rape"); Amy Dellinger Page, Behind the Blue Line: Investigating Police Officers' Attitudes Toward Rape, 22 J. POL.ICE \& CRIM. PsYCHOL. 22, 24 (2007) (finding that female officers are significantly less accepting of rape myths than male police officers); $c f$. Kathryn B. Anderson et al., Individual Differences and Attitudes Toward Rape: A Meta-Analytic Review, 23 Personnlity \& Soc. Psychol. Bul.l. 295, 298 (1997) (finding that men are more accepting of rape myths than women). One researcher found negative attitudes toward rape victims among women personnel similar to their male colleagues. See Jordan, Will Any Woman Do?, supra note 135, at 331. This may be because "organizational culture, socialization, and peer pressure can influence personal attitudes" regarding rape myths in the workplace, and "police officers are more likely to endorse rape myths than ... the general public." Rich \& Seffrin, supra note 104, at 264-65. However, we argue that having more women officers could shift the culture of police departments and change male officers' views on rape. See infra notes 168-77 and accompanying text.

${ }^{146}$ See Diana L. Payne et al., Rape Myth Acceptance: Exploration of Its Structure and Its Measurement Using the Illinois Rape Myth Acceptance Scale, 33 J. Res. Person- 
Furthermore, some studies indicate that female officers may be more supportive of victims because they have lower levels of acceptance for aggression against women than male police officers. ${ }^{147}$

Although the experiences and culture of individual agencies may differ, ${ }^{148}$ large-scale studies indicate that the presence of women law enforcement officers actually increases the number of reported sexual assault cases. In 2006, a study analyzed the relationship between the percentage of women police officers, the number of reports of sexual assault, and the number of arrests for sexual assault in sixty urban areas over an eight-year period. ${ }^{149}$ The study found that the percentage of women police officers positively correlates with both reports and arrests for sexual assault. ${ }^{150}$ More recently, a 2014 study of domestic violence crime data from the National Crime Victimization Survey indicates that increasing the number of female police officers tends to raise reporting of violent crimes against women. ${ }^{151}$ Additionally, the data also led to the conclusion that such an increase actually improves police quality. ${ }^{152}$

\section{A Call for More Women Officers on Campus}

In this Part, we argue that to reduce the hostile environment for women students - who suffer a heavily disparate impact from sexual crimes ${ }^{153}$ - and to offer them the full benefits of higher education, colleges and universities should make meaningful efforts to hire more women officers. ${ }^{154}$ Substantial

ALITY 27, 30-31, 64 (1999). For an updated Rape Myth Acceptable Scale, see Sarah McMahon \& G. Lawrence Farmer, An Updated Measure for Assessing Subtle Rape Myths, 35 Soc. WORK Res. 71, 77 (2011). The scale is archived at http://perma.cc/4SUTS6HV.

${ }_{147}$ See Brown \& King, supra note 145, at 273.

${ }^{148} \mathrm{Cf}$. Meghan A. Alderden \& Sarah E. Ullman, Gender Difference or Indifference? Detective Decision Making in Sexual Assault Cases, 27 J. INTERIPERSONAL ViolenCe 3, 13-15 (2012). This 2012 study of a large Midwestern police department found that after a report of rape, female detectives were significantly less likely than male detectives to arrest the suspect, and efforts to hire more women may "undermine efforts to improve victim experiences with the criminal justice system." Id. at 3-4. We do not find that study compelling for several reasons. First, it examined arrests, which come after the actual report of the crime. We have argued here that an increase in reporting is an essential first step in reducing crime. See supra notes 79-96 and accompanying text. Second, the authors did not address the type of training that officers received at the one agency, and we have made the case that training is essential to avoid victim blaming once an officer investigates a report. See infra notes 198-203 and accompanying text; see also Human Rts. Watch, Improving Police Response to Sexual. Assault 10 (2014), archived at http://perma.cc/5ARF-7JG9.

${ }_{149}$ Meier \& Nicholson-Crotty, supra note 135 , at 856.

${ }^{150} \mathrm{ld}$.

151 Miller \& Segal, supra note 120, at 4.

152 Id.

${ }^{153}$ Dear Collengue Letter, supra note 27 , at 2.

154 We neither recommend nor suggest specific quotas, which are constitutionally impermissible at public institutions. See City of Richmond v. J.A. Croson Co., 488 U.S. $469,507-08,511$ (1989) (striking down city's use of a quota system for minority employ- 
evidence that the heightened presence of female police officers tends to increase the reporting of violent crimes against women 155 should incentivize universities to boost the hiring and retention of female officers. These data justify hiring women not simply to ensure that the demographics of agencies reflect the population they serve, but more importantly to improve the agency's ability to protect women. Moreover, genuine efforts to maintain a significant number of women on their police force can bolster the legal position of universities when facing charges of violations of Title IX. ${ }^{156}$

The case for increasing the number of women police officers at universities to increase reporting is also supported by the theory of representative bureaucracy. ${ }^{157}$ Representative bureaucracy theory holds that when bureaucratic agencies are made up of individuals who represent the people they serve on important demographic and social indicators, the agency makes decisions that benefit the marginalized people they serve. ${ }^{158}$ Used frequently to explain the importance of including racial diversity in bureaucratic structures, ${ }^{159}$ bureaucratic representation ${ }^{160}$ has more recently been applied to gen-

ment in the construction industry); Regents of Univ. of Cal. v. Bakke, 438 U.S. 265 , 319-20 (1978) (finding that medical school's policy of setting aside seats for designated number of minority students in admissions process violated the Fourteenth Amendment); Gratz v. Bollinger, 539 U.S. 244, 270-76 (2003) (holding rigid point system giving preference to minorities in university's admissions process violated Equal Protection Clause). By contrast, race- and gender-conscious recruiting efforts have been upheld. See, e.g., Peightal v. Metro. Dade Cnty., 26 F.3d 1545, 1557-58 (11th Cir. 1994) (upholding district court's determination that fire department's recruiting program targeting women and minorities was "race neutral"); Weser v. Glen, 190 F. Supp. 2d 384, 399 (E.D.N.Y. 2002) ("[E]ven if the Law School's recruiting and outreach efforts were 'race conscious' in being directed at broader recruiting of minorities and women, such efforts would not constitute discrimination."); Pennsylvania. v. Flaherty, 760 F. Supp. 472,488 (W.D. Pa. 1991) (noting that city could continue actively recruiting women and minorities for positions on the police force). For guidance on how to recruit women officers, see generally Karen Oehme, Fi a. State Univ., A Guide for Campus law Enforcement Agencies: How to Recruit Female OfFicers (2015), archived at http://perma.cc/4U67-EX8Z.

${ }^{155}$ See supra notes $149-53$ and accompanying text.

${ }^{156}$ See infra notes $211-41$ and accompanying text.

${ }^{157}$ Meier \& Nicholson-Crotty, supra note 135, at 852.

${ }^{158} \mathrm{Id}$. at 851 .

159 See, e.g., Jason A. Grissom et al., Race, Religion, and Representative Bureaucracy, 69 Pub. Admin. Rev. 911 , 912 (2009); Rene R. Rocha \& Daniel P. Hawes, Racial Diversity, Representative Bureaucracy and Equity in Multiracial School Districts, Soc. ScI. Q. 326, 331 (2009).

${ }^{160}$ This concept differs from the "community policing" movement promoted by the Department of Justice for the last two decades. Community policing focuses more on community partnerships, organizational change, and increasing police legitimacy than on agency diversity. See U.S. Cmty. Oriented Policing Servs., Dep't. of Justice, ComMUNITY Pol.icing Defined 2-7 (2012) (rev. 2014), available at http://ric-zai-inc.com/ Publications/cops-p157-pub.pdf; Charlotte Gill et al., Community-Oriented Policing to Reduce Crime, Disorder and Fear and Increase Satisfaction and Legitimacy Among Citizens: A Systematic Review, 10 J. Experimental, Criminology 399, 403 (2014). Gill conducted a meta-analysis of twenty-five different reports and thirty-seven independent tests that evaluated the effectiveness of community policing. Id. at 399 . The researchers found community policing effective in increasing community satisfaction and perception of police, $i d$. at 413 , but less effective in reducing actual crime rates or the fear of crime, id. at 419. For further discussion of the effectiveness of community policing, see Commu- 
der. Bureaucratic representation occurs at two levels: passive representation and active representation. ${ }^{161}$ Passive representation is the process of simply having a bureaucracy that has adequate representation of demographic characteristics of the people the bureaucracy serves. ${ }^{162}$ Clients are more inclined to access bureaucratic services because they know the agency comprises, in significant part, individuals who resemble them; that is, clients see a visible connector and are more likely to use the services because of an observable similarity. ${ }^{163}$ Commentators have pointed out, for example, that the recent problems in Ferguson, Missouri stemming from a white police officer shooting a black man could have had roots in the stark racial divisions of the community and police force. ${ }^{164}$ The implication is that police agencies can benefit from simply being more representative of the communities they serve. Under the theory of passive representation, a university law enforcement agency intrinsically helps the school's women students when the agency's makeup reflects to an appreciable degree the gender composition of the student population. 165

Even just increasing the representation of women on a campus police force ensures benefits to female victims of sexual assault. First, women students who see women law enforcement officers engaging in routine policing activities may be more inclined to turn to the agency after a rape. Women students are undoubtedly familiar with the demographic makeup of the campus police force simply because they routinely interact with police throughout their college experience. Just as a woman is likely to notice how often she sees a "female police officer working security, patrolling a beat, or cruising a neighborhood," 166 students observe campus police patrolling campus, engaging in traffic and parking enforcement, performing building lockup, responding to calls for service by other students reporting crimes, and police presence at campus special events ${ }^{167}$ such as commencement, sports competitions, concerts, large club proceedings, public meetings, and

nity Policing and Procedural Justice, CTr. For Evidence-Based Crime Pol'y, Gro. MASON UNIV., http://cebcp.org/evidence-based-policing/what-works-in-policing/research-evidence-review/community-policing/, archived at http://perma.cc/TKT3-SNCT; Christopher Moraff, Why Community Policing is Still a Good Investment, Next Ciry (Sept. 15, 2014), http://nextcity.org/daily/entry/community-policing-efforts-success-failure, archived at http://perma.cc/Y9G4-WMYS.

161 See Meier \& Nicholson-Crotty, supra note 135, at 851.

${ }_{162}$ See id.

${ }^{163} \mathrm{Id}$. at 852 .

${ }^{164}$ See, e.g., Braden Goyette, Stark Racial Disparities in Ferguson, Missouri, the Town Where Michael Brown Was Shot, Hufrington Post (Aug. 13, 2014), http://www .huffingtonpost.com/2014/08/12/racial-disparities-ferguson-missouri_n_5671891

.html\&gt, archived at http://perma.cc/6GN9-CYV7 (emphasizing that although Ferguson, Missouri's population is two-thirds black, the town's leadership and police force are dominated by white people).

${ }^{165}$ See Meier \& Nicholson-Crotty, supra note 135, at 852.

${ }^{166} \mathrm{Id}$.

${ }^{167}$ See Reaves, supra note 116, at 4 (listing functions performed by campus law enforcement agencies). 
public safety programs. Studies have also suggested that women are especially aware of the gender mix in their environment. ${ }^{168}$ Thus, before a rape even occurs, women students will have noticed that the campus law enforcement agency includes many women officers. By seeing women law enforcement officers patrolling, responding, and investigating, women who are victimized may be more inclined to report their experience because of the belief that their experience is shared and represented by officers within the agency, regardless of the gender of the actual responding officer. ${ }^{169}$

Under the concept of active representation within representative bureaucracy theory, another advantage of hiring more women police officers is the effect their presence may have on the practices and explicit policies and procedures of the agency. ${ }^{170}$ When bureaucracies are composed of disenfranchised members who have power and autonomy within the agency, decisions are made that positively impact the disenfranchised population. ${ }^{171}$ Well-documented in the case of minority representation within bureaucracies, ${ }^{172}$ the theory has more recently been applied to professions that are comprised of a majority of one gender. ${ }^{173}$ As such, a meaningful increase in women's representation within law enforcement agencies has the potential to positively impact rape victims. For example, women officers' presence may influence their male colleagues' views of rape. Researchers have theorized that the presence of more women officers at law enforcement agencies works to sensitize male officers to the issues involved in sexual assault and its impact on victims. ${ }^{174}$

The actual effects of greater representation of women on male officers' attitudes within agencies have not been studied extensively. ${ }^{175}$ It seems clear,

${ }^{168}$ Cf. Marco Castillo et al., Room Effects 1-2 (Interdisciplinary Ctr. for Econ. Sci. George Mason Univ., Working Paper No. 13-17, 2013), available at http://papers.ssrn .com/sol3/papers.cfm?abstract_id=2280217 (finding evidence that the gender composition of the room significantly alters the risk decisions of women).

${ }^{169}$ Meier \& Nicholson-Crotty, supra note 135 , at 852.

${ }^{170} \mathrm{ld}$. at 851 .

${ }^{171} I d$.

172 See Mark D. Bradbury \& J. Edward Kellough, Representative Bureaucracy: Exploring the Potential for Active Representation in Local Government, 18 J. PUB. Admin. RESEARCH \& THEORY 697, 697, 706-07, 712-13 (2008) (finding that diversity within the public workforce will help to ensure that the interests of diverse groups are represented in policy formulation and implementation processes and that in historically disadvantaged communities, African-American administrators support the needs of their African-American constituents better and increase active participation in government through common interests and attitudes); Nick A. Theobald \& Donald P. Haider-Markel, Race, Bureaucracy, and Symbolic Representation: Interactions Between Citizens and Police, 19 J. PuB. Admin. ResEARCh \& THEORY 409, 410-11 (2008) (finding that black citizens are more likely to perceive police actions as legitimate if there are black officers present, and white citizens are more likely to perceive police actions as legitimate if there are white officers present).

${ }^{173}$ See Meier \& Nicholson-Crotty, supra note 135, at 858 (citing studies applying this theory to female teachers and female students, women child support enforcement officers, and child support collections).

${ }^{174} I d$. at 853 .

${ }^{179}$ See id. at 858. 
however, that an individual agency's mere touting of its decision to hire a handful of additional women police officers is not likely to result in meaningful change throughout the agency or campus. ${ }^{176}$ Indeed, those few officers may simply absorb the well-established, male-dominated agency culture ${ }^{177}$ and reflect that culture in their attitudes and behaviors. ${ }^{178}$ At any rate, a token number of female officers would not fulfill the purposes of attaining ample representation of women in campus (and other) law enforcement agencies. To attain these goals, agencies must endeavor to hire, train, and retain women at every level of the organization. Women law enforcement officers who represent a small minority of the force-despite making up approximately half the population (more on most campuses) - have not reached the critical mass ${ }^{179}$ necessary to influence culture and policy within the institution. ${ }^{180}$ When the number of women reaches a critical mass, women officers may help shift the agency toward more effectively addressing sexual violence against women. This representation also needs to be incorporated throughout the ranks, so that women officers hold positions of power within the agency that can influence policy and procedural decisions. ${ }^{181}$ This is particularly relevant to the issue of sexual assault, because officers routinely

${ }^{176}$ See MARTIN \& JURIK, supra note 118, at 71 (stating that when women comprise only a small proportion of officers, they are merely "tokens" and are treated paternalistically).

177 See Deborah Parsons \& Paul Jesilow, In The Same Voice: Women and Men IN LAW ENFORCEMENT 31 (2001) (stating that police work is perceived to "require characteristics usually attributed to men, for example, aggression, physical prowess, logic, and stability of emotions. Characteristics commonly considered feminine, such as compassion, empathy, nurturing, and strong emotions, are frequently perceived to be weaker, less appealing, less successful, and especially in terms of policing, possibly dangerous and life-threatening"); Mary Dodge et al., Maintaining Separate Spheres in Policing: Women on SWAT Teams, 20 WOMEN \& CRIM. JuST. 218, 224 (2010) ("Many observers have asserted that regular . . . policing is infused with a large dose of masculine values that shape how and why police work is performed and that the 'right' way to maintain social order and control is to have men perform police work ...." (citations omitted)).

178 Rich \& Seffrin, supra note 104, at 264 (noting that "organizational culture, socialization, and peer pressure may influence personal attitudes").

${ }^{179}$ The concept of a critical mass originates in nuclear physics. As Thomas Schelling wrote, some minimum amount of fissionable material must be compacted together to create self-sustaining nuclear fission; once there is enough of this material, an atomic pile "goes critical." Thomas C. Schelling, Micromotives AND Macrobehavior 89 (1978). In social science, critical mass refers to "getting together enough resources to accomplish some goal ... [I]t takes some minimum number of people or some minimum accumulation of seed money to draw in the participation and contributions of others." Gerald Marwell \& Pampla Oliver, The Critical Mass in Collective Action: A Micro-SOCIAL ThEORY 1 (1993). For further discussion of critical mass in social science and collective action, see generally $i d$.

${ }^{180}$ Lael R. Keiser et al., Lipstick and Logarithms: Gender, Institutional Context, and Representative Bureaucracy, 96 AM. PoI.. SCI. Rev. 553, 557 (2002) ("A critical mass may be needed for minorities to take an advocacy role .... Organizations with a critical mass of women will be more likely to allow for active representation.").

${ }^{181}$ See $i d$. at 553, 562 (finding that having increased numbers of women in positions of power ("passive representation") "has consequences for the policy benefits the bureaucracy produces for women"). 
hold much discretion in deciding whether to make an arrest, ${ }^{182}$ and an officer's use of discretion is undoubtedly linked to agency culture and attitudes about rape and rape victims. ${ }^{183}$ Adequate representation of trained women officers has the potential to sway this discretionary power toward victimcentered practices and away from the victim-blaming attitude so prevalent today. ${ }^{184}$

Further, increases in reporting can produce results that will ultimately effect a reduction in sexual assaults on campus. A higher number of reports can lead to better data on the prevalence of assault, more investigations, more arrests, and thus more consequences for offenders. Colleges and universities can then achieve tangible gains by immediately increasing their efforts to hire more women police officers. As the number of female officers rises, students will more frequently report sexual assaults. ${ }^{185}$ As the rate of reporting goes up, universities will be able to garner more resources such as advocates and officers, conduct more campus trainings and programs, and work to overhaul the campus environment to reduce commission of the crime.

A further long-term benefit of more reporting of rape is that it provides campus authorities with better campus crime data. ${ }^{186}$ An increase in the number of sexual assault reports by victims to police can lead to better assessment of the specifics of the crime (e.g. where the assault was perpetrated), as well as a statistical likelihood that there will be an increase in the number of arrests (regardless of the gender of the officer). Increased reporting will make Clery reports more accurate while also providing helpful information to police for investigative purposes. This data is likely necessary for agencies to tailor specific local policies and programs for prevention and intervention. Such data will help agencies advocate and gain support for the financial resources they need to put those specific programs and policing into place. ${ }^{187}$ One example of a specific policy decision that could result

${ }^{182}$ Wayne A. Kerstetter, Gateway to Justice: Police and Prosecutorial Response to Sexual Assaults Against Women, 81 J. CRIM. L. \& CRIMINOLOGY 267, 298 (1990) (stating that when officers have information about the identity of the perpetrator, "they have greater discretion over whether or when they will apprehend the accused").

${ }^{183}$ Annelise Mennicke et al., Law Enforcement Officers' Perception of Rape and Rape Victims: A Multimethod Study, 29 Violence \& Victims 814, 815-16 (2014); cf. Kimberly A. Lonsway \& Joanne Archambault, End Violence Against Women Int'l, Dynamics of Sexual Assault: What Does Sexual Assault Really look LIKE? 13-14 (2014), available at http://olti.evawintl.org/images/docs/DYNAMICS\%2001-25-13.pdf ("[T]he . . . stereotypic characteristics of 'real rape' increase the likelihood that a case will have charges filed.").

${ }^{184}$ See Campbell et al., supra note 103, at 1240; see also supra notes 105-12 and accompanying text.

${ }^{185}$ Cf. supra notes $149-53$ and accompanying text.

${ }^{186}$ See supra notes 79-82 and accompanying text.

${ }^{187}$ See Climate Surveys: Useful Tools to Help Colleges and Universities in Their Efforts to Reduce and Prevent Sexual Assault, Not Alone, https://www.notalone.gov/ assets/ovw-climate-survey.pdf, archived at https://perma.cc/Q343-VQSN ("[D]ecades of research [show] that victims rarely report sexual assault to law enforcement. Many 
from increased reporting to police of campus sexual assault is an increase in hiring people who provide victim support. For example, universities could justify increasing the number of victim advocates. These are advocates trained to support victims by helping them obtain emergency medical care and report sexual assaults to local law enforcement and providing information on their legal rights, availability of counseling, and other services. ${ }^{188}$ Similarly, increased reporting by victims could result in universities spending more resources to purchase and administer bystander training programs ${ }^{189}$ for staff and students.

This Article's proposal comes at a time of apparently heightened receptivity to the greater inclusion of women in law enforcement agencies. Even though it may be difficult for some agencies to attract women recruits, ${ }^{190}$ evidence points to a growing recognition of the need for more women officers on campus. Several universities and student groups have recognized the problems of campus rape, the underreporting of the crime, and the need for more women police officers. The University of Rochester issued a statement to the local newspaper when a sexual assault survivor complained that she was never offered the chance to speak with a female officer after she was assaulted at a fraternity party. ${ }^{191}$ The university said it was training new female officers "who will be able to investigate and respond to complaints of sexual misconduct." ${ }^{192}$ In 2013, the Student Government Association ("SGA") of Connecticut College responded when the college's Campus

victims do not even access formal services, like crisis centers. Thus, official statistics underrepresent the extent of the problem on any one campus. Further, campus response, intervention, and prevention efforts will be more successful if they are tailored to the needs of each campus community.").

${ }^{188}$ See Key Components of Sexual Assault Crisis Intervention/Victim Service Resources, NOT ALONE 1, https://www.notalone.gov/assets/intervention-resources.pdf, archived at https://perma.cc/MPD4-E9JM ("Victims who worked with advocates got better treatment in the medical system and showed lower distress after medical exams. Having an advocate also improved experiences with the legal system."); What is a Victim Advocate?, NAT'L. CTR. FOR VICTIMS OF CRIME (2008), http://www.victimsofcrime.org/ help-for-crime-victims/get-help-bulletins-for-crime-victims/what-is-a-victim-advocate, archived at http://perma.cc/A4M6-G6Z2.

${ }_{189}$ For background on bystander training programs, see Nat'l Srexual Violence Res. Ctr., It's Time . . . to Incorporate the Bystander Approach into Sexual Violence Prevention 2 (2011) ("[B]ystander education prevention programs provide chances to build skills for helping directly or indirectly without placing bystanders' safety in jeopardy by focusing on practicing intervention strategies.").

${ }^{190}$ See Jeremy M. Wilson \& Clifford A. Grammich, RAND Ctr. on Quality Poljacing, Pollice Recruitment and Retention in the Contemporary Urban Environment: A National Discussion of Personnel. Experiences and Promising PracTICES FROM THE FRONT LINES 7, 12, 15-16 (2009) (discussing the difficulty of recruiting women, as well as how agencies have made efforts to make police careers appeal to women and minority applicants).

${ }_{191}$ James Goodman \& Neeti Upadhye, Campuses Struggle with Sex Assault Cases, Democrat \& CHRON. (Aug. 26, 2014), http://www.democratandchronicle.com/story/ news/2014/08/23/colleges-university-rochester-sexual-misconduct/14466731/, archived at http://perma.cc/A4MM-A9A8.

${ }_{192} I d$. 
Safety Officer Search Committee sought to hire a new police officer. ${ }^{193}$ The SGA put forth a resolution emphasizing the importance that the new officer identify as a woman, since over half of the college's student body is female. ${ }^{194}$ As of 2014, only $17 \%$ of officers on staff at the University of West Virginia were female, but in a newspaper article, the Police Chief expressed the desire for more female officers. 195 "In our environment on campus, I think having a large amount of female officers works well," the Chief said. "People can relate and interact better with some of our female officers because they have different skill sets." 196 Just a few months earlier, the student newspaper at Stony Brook University opined that "some solutions" to sexual assaults on campus included hiring more police female officers, re-orienting a portion of the police force to focus on helping victims, increasing self-defense training, and creating bystander awareness workshops. ${ }^{197}$

It is important to bear in mind that the proposal to increase the number of women in campus law enforcement agencies in order to increase reporting of sexual assault is intended as a complement to, not substitute for, the proper training of officers in dealing with sexual violence. Indeed, training is essential for all officers on the various dimensions of sexual assault: communication skills for working with victims, ${ }^{198}$ the legal elements of the crime under state law, ${ }^{199}$ and the low estimate of false rape claims. ${ }^{200}$ Working with

${ }^{193}$ Ryan Friend, Students, SGA Push for Hiring of Woman Campus Safety Officer, Coll. VOICE (Nov. 19, 2013), http://thecollegevoice.org/2013/11/19/students-sga-pushfor-the-hiring-of-woman-campus-safety-officer/, archived at http://perma.cc/6L3G-UH 99.

${ }^{194} \mathrm{Id}$. (stating that $55 \%$ of the college's student body is female).

${ }^{195}$ Hannah Wigal, Morgantown Law Enforcement Agencies Report Few Female Officers on Staff, Dally Athenasum (Sept. 2, 2014), http://m.thedaonline.com/news/article_ee86c730-29b0-11 e4-bf49-0017a43b2370.html?mode=jqm, archived at http://perma .cc/8K3Z-4FMM.

${ }^{196} \mathrm{Id}$.

${ }^{197}$ Paul Grindle \& Alexandra Miller, Sexual Assault Increases on Campus, StatesMAN (Mar. 6, 2014), http://sbstatesman.com/2014/03/06/sexual-assault-increases-on-campus/, archived at http://perma.cc/JH8X-YX9A; see also Joshua Lim, OUPD Hired Second Female Officer, Still Desires Diversity, Post (Oct. 6, 2014), http://www thepostathens.com/news/article_9b4e047e-4cde-11e4-a653-0017a43b2370.html, archived at http://perma.cc/G7VG-V7LD (discussing Ohio universities' desire for and efforts to recruit more female police officers).

${ }^{198}$ Rich \& Seffrin, supra note 104 , at 266-67.

${ }^{199}$ Rebecca Campbell \& Camille R. Johnson, Police Officers' Perceptions of Rape: Is There Consistency Between State Law and Individual Beliefs?, 12 J. INTERPERSONAL VIOLENCE 255, 271 (1997).

${ }^{200}$ See, e.g., Kimberly Lonsway et al., False Reports: Moving Beyond the Issue to Successfully Investigate and Prosecute Non-Stranger Sexual Assault, 3 VoIce 1, 2, 5 (2009) (finding that only about $2 \%$ to $8 \%$ of rape allegations are false); Yung, supra note 8 , at 6 ("[I]ndividuals working at universities would be expected to have . . . unconscious beliefs that might lead them to undercount on-campus incidents of sexual violence .... [E]xaggerated belief in false reporting are the prime culprits in such pervasive hostility to sexual assault complaints." (citation omitted)); see also DAvid FARRINGTON et Al., Evidence-Based Crime Prevention 109 (2002) ("According to FBl statistics, false accusations of rape are no more common than for other crimes."). 
victim advocates to combat stereotypes of a what a "real victim"201 looks or acts like, ${ }^{202}$ dispelling other myths about sexual violence, and developing a culture of sensitivity toward rape victims is essential for all campus law enforcement-women and men-to appropriately respond to a victim's report. ${ }^{203}$ Such training is crucial to ensure that when a victim does report to police, she is not re-traumatized by the responding officer.

Likewise, the role of victim advocates ${ }^{204}$ and campus mental health professionals is an essential one, and we support their status as confidential assistants to victims. ${ }^{205}$ It is vital for victims to have a trained advocate who can provide assistance ${ }^{206}$ in a confidential environment, ${ }^{207}$ and victims must retain the ability to decide whether or not to report to campus law enforcement. If victim advocates lost their confidentiality privilege, reporting numbers would sink even lower, making the fight against sexual assault even more difficult. ${ }^{208}$ Our proposal instead is to encourage women to feel comfortable reporting to trained campus police, which in turn will trigger victim assistance services, hold perpetrators accountable, and better enable universities to obtain the resources they need to combat this crime. Thus, reporting rates and assistant services are mutually reinforcing: as reporting rates rise to

${ }^{201}$ See Janice Du Mont et al., The Role of "Real Rape" and "Real Victim" Stereotypes in Police Reporting Practices of Sexually Assaulted Women, 9 VIOLENCE AGAINST WOMEN 466, 477 (2003).

${ }^{202}$ See Jan Jordan, Beyond Belief? Police, Rape and Women's Credibility, 4 CRIM. Just. 29, 37 (2004) (describing factors that officers say diminish victims' credibility, including a victim being drunk/drugged, delaying reporting, having had a previous sexual relationship with the offender, or a previous report of sexual victimization).

${ }^{203}$ Jordan, Will Any Woman Do?, supra note 135, at 319 (" $[\mathrm{N}]$ ot only is it possible for some male officers to be sensitive victim interviewers, but also that being female does not automatically denote possession of the key attributes required for victim interviewing. Some rape complainants, however, expressed a strong preference for women officers. This places the onus on the police not simply to provide a woman officer-the 'any woman will do' scenario-but to ensure the availability of trained and experienced women and men officers.").

${ }^{204}$ See What is a Victim Advocate?, supra note 188.

${ }^{205}$ See Catherine E. Lhamon, U.S. Dep't of Educ., Questions and Answers on Title IX AND SeXuAL ViolenCe 22-23 (2014), archived at http://perma.cc/8DCH-6D7K (stating that professionals with licensure that requires confidentiality include "mentalhealth counselors, pastoral counselors, social workers, psychologists, health center employees" and supporting that schools not require "all individuals who work or volunteer in on-campus sexual assault centers, victim advocacy offices, women's centers, or health centers" to report incidents of sexual violence in a way that identifies the victim without her consent).

${ }^{206}$ See Rebecca Campbell, Rape Survivors' Experiences with the Legal and Medical Systems: Do Rape Victim Advocates Make a Difference?, 12 VIOLENCE AGAinst Women 30,30 (2006) (finding that survivors who had the assistance of an advocate were significantly more likely to have police reports taken, less likely to be treated negatively by police officers, less distressed after their contact with the legal system, and received more medical services).

${ }^{207}$ See Lhamon, supra note 205, at 23 ("These non-professional counselors or advocates are valuable sources of support for students, and OCR strongly encourages schools to designate these individuals as confidential sources.").

${ }^{208}$ See Campbell, supra note 206, at 36. 
accurately reflect the true incidence of the campus crime, so will the use and availability of services..$^{209}$

Finally-and of considerable legal significance-universities should recognize that hiring and appropriately training more women police officers can serve their own institutional interest as well as the interests of their students by helping to bring schools into compliance with Title IX. The sheer horror of frequent sexual assault on campus reflects a hostile environment that traumatizes women students every day. ${ }^{210}$ Under certain circumstances, schools have a duty to take prompt and effective action to stop this victimization and prevent its recurrence. ${ }^{211}$ If the school fails to take the necessary steps, it has engaged in discrimination, because its failure to act has allowed a hostile environment that denies or limits the student's ability to benefit from the school's program to continue. ${ }^{212}$

Sexual assault victims have two remedies under Title IX: complainants can file a complaint with the Office of Civil Rights and sue the educational institution in civil court. ${ }^{213}$ Both types of remedies can result in changes to the university's response to the problem of sexual assault. ${ }^{214}$ Anyone can report a Title IX complaint with the Office of Civil Rights (OCR) at the Department of Education within 180 days of the alleged discrimination. ${ }^{215}$ If the OCR's investigation finds a violation of Title IX, the usual outcome is a voluntary resolution between the OCR and the school. ${ }^{216}$ This forces changes in the institutions' response systems. ${ }^{217}$ Several high-profile Title IX complaints to the OCR illustrate this remedy. For example, in 2012, Yale University entered into a settlement agreement without any finding of fault by the

${ }^{209}$ Cf. Sexual Assault: Victim Right, Reporting and Resources, U.C. IRvine, http:// www.care.uci.edu/general/Sexual-Assault-Victim-Rights-Reporting.aspx, archived at http://perma.cc/X6HD-ZPV7 ("Reporting may also help to ensure that you receive the most immediate and comprehensive professional assistance that is available. The police will assist you in getting specialized medical care . . . and resolving concerns about your personal safety and security.").

${ }^{210}$ Cf. Revised Sexuni. Harassment Guidance, supra note 54, at 7 ("A series of incidents at the school, not involving the same students, could taken together create a hostile environment, even if each by itself would not be sufficient.").

${ }^{211} \mathrm{Id}$. at 12 (stating that schools are required to take action when "the harassing conduct is sufficiently serious to deny or limit the student's ability to participate in or benefit from the program, and if the school knows or reasonably should know about the harassment" (footnote omitted)).

${ }^{212}$ Id. at 3,5 .

${ }^{213}$ Title IX in Detail, KNow Your IX, http://knowyourix.org/title-ix/title-ix-in-detail/, archived at http://perma.cc/CXZ6-HVDW.

${ }^{214}$ See infra notes 216,223 and accompanying text.

${ }^{215}$ See Anne E. Clark \& Miriam Hauser, How to File a Title IX Complaint, KNow Your IX, http://knowyourix.org/title-ix/how-to-file-a-title-ix-complaint/, archived at http://perma.cc/6WA8-YD7P; Questions and Answers on OCR's Complaint Process, U.S. DEP'T EDUC. (Nov. 16, 2011), http://www2.ed.gov/about/offices/list/ocr/qa-complaints .html, archived at http://perma.cc/3HME-4V6K.

${ }^{216}$ Lauren P. Schroeder, Cracks in the Ivory Tower: How the Campus Sexual Violence Elimination Act Can Protect Students from Sexual Assault, 45 LOY. U. CH. L.J. 1195, 1207 (2014).

${ }^{217}$ Id. 
$\mathrm{OCR}^{218}$ after sixteen students accused it of creating a sexually hostile environment - by allowing such activities as fraternities holding up a sign saying "We love Yale sluts" and chanting "no means yes" on campus-and by failing to adequately respond to complaints of rape and stalking. ${ }^{219}$ Notably, complainants described the school environment as devaluing to women and perpetuating an atmosphere in which sexual harassment is acceptable. ${ }^{220}$ As part of its OCR resolution agreement, the school agreed to publish a twiceyearly report documenting all complaints of sexual misconduct on campus. ${ }^{221}$ Still, the university was subsequently criticized for allowing alleged perpetrators of sexual assault to remain on campus. ${ }^{222}$ After an OCR complaint, Tufts University hired a Title IX coordinator, developed informational materials for students on sexual misconduct, and provided training for students. ${ }^{223}$

The relief from Title IX lawsuits, on the other hand, is typically monetary compensation to victims who prevail, but may also include payments of attorney's fees and injunctive relief. ${ }^{224}$ For example, the University of Colorado agreed to pay a student $\$ 2.5$ million and hire a Title IX advisor who would "make recommendations concerning the final disposition of any University investigation or disciplinary proceeding arising from the sexual abuse of a student." 225 The university agreed to provide a "written explanation in any instance where the University does not adopt the Title IX advisor's recommendation." 226 Similarly, when five students sued the University of Connecticut for its handling of their sexual assault allegations, a monetary settlement of nearly $\$ 1.3$ million for those students resulted. ${ }^{227}$ While the university admitted no wrongdoing, it issued a statement acknowledging the role of the five students in "inspiring important public discussion." 228 After the settlement, the university put new measures in place to prevent and respond to sexual assault, including establishing an assistant dean of students position for victim support services, adding staff investigator positions, and

${ }^{218} \mathrm{Id}$. at 1206 .

${ }^{219}$ John Christoffersen, Yale Under Federal Investigation for 'Sexually Hostile Environment,' HuFFINGTON POST (Apr. 1, 2011 ), http://www.huffingtonpost.com/201 1/04/01/ yale-title-ix_n_843570.html, archived at http://perma.cc/EV5Q-M8JZ (describing the sexually hostile environment).

$220 \mathrm{Id}$.

221 Schroeder, supra note 216 , at 1206.

$222 \mathrm{Id}$.

${ }^{223}$ See Letter from Thomas J. Hibino, U.S. Dep't of Educ., to Anthony P. Monaco, Tufts Univ. President 14-16 (Apr. 28, 2014), archived at https://perma.cc/2DSG-T86T. ${ }^{224}$ Schroeder, supra note 216 , at 1210.

${ }^{225}$ Grayson Sang Walker, The Evolution and Limits of Title IX Doctrine on Peer Sexual Assault, 45 HARv. C.R.-C.L. L. REv. 95, 124 (2010) (citation omitted).

$226 \mathrm{Id}$.

${ }^{227}$ Jake New, Major Sexual Assault Settlement, INSIDE Higher Ed (July 21, 2014), https://www.insidehighered.com/news/2014/07/21/u-connecticut-pay-13-million-settlesexual-assault-lawsuit, archived at http://perma.cc/KG6N-H9G8.

228 Id. 
creating a Special Victims Unit in the university police department. ${ }^{229}$ In a lawsuit involving Arizona State University ("ASU"), the student survivor agreed to "release and forever relinquish any and all claims she possesses against [ASU]" in exchange for $\$ 850,000$ and ASU's promise to conduct "a review of [its] policies on sexual harassment and implement changes as needed." ${ }^{230}$ In addition, a newly hired Student Safety Coordinator for the three public universities in Arizona was ordered to publish an annual report describing actions taken by those universities for each of the next five years. ${ }^{231}$ The complainant reportedly agreed to settle the case because she believed "the non-monetary terms of the settlement [would] make a significant contribution to making Arizona's campuses safer and reducing the risk of sexual harassment and assault for all students." 232

As described above, the remedies for Title IX violations can go beyond the recommendations of the "Dear Colleague" letter from the Office of Civil Rights. Though remedies include a variety of measures with the potential to change university culture, a necessary first step in combatting the crime is to encourage students to come forward so that schools must address campus sexual assault. ${ }^{233}$ Our proposal provides universities with an additional way to demonstrate that the university values the role of women, thereby directly contributing to an environment that does not tolerate sexual discrimination, harassment, and assault. It is also an opportunity for the university to demonstrate that the university is not trying to shield itself from knowledge of problems on campus and is not deliberately indifferent to them. ${ }^{234}$ Conversely, the lack of female police officers on a university campus can be used as one element in a legal claim that the university is deliberately indifferent to the issue of sexual assault. Although this legal argument has not been tested, we believe that the lack of female officers contributes to an overall campus atmosphere in which sexual harassment is more likely to thrive.

Under this view of Title IX, then, a plaintiff's evidence of a university law enforcement agency's lack of consistent, ongoing, and genuine effort to hire sworn female officers contributes to the plaintiff's allegation of a hostile educational environment. Such lack of effort can help demonstrate that the school has not taken the type of appropriate steps it needs to increase resources for women on campus. By the same token, a university's demonstra-

${ }^{229} \mathrm{Id}$.

${ }^{230}$ Walker, supra note 225 , at 126 (alternations in original) (citations omitted).

${ }^{231} I d$.

${ }^{232} I d$. (alternations in original) (citations omitted).

${ }^{233}$ Schroeder, supra note 216 , at 1205-06 ("If it is determined that sexual assault has occurred, a school must take immediate action to eliminate the hostile environment, prevent its recurrence, and address its effects." (citation omitted) (internal quotation marks omitted)).

${ }^{234}$ See, e.g., Davis ex rel. LaShonda D. v. Monroe Cnty. Bd. of Educ., 526 U.S. 629, 631 (1999) (holding that Title IX violations only exist where schools are "deliberately indifferent" to acts of sexual harassment). 
bly consistent, ongoing, and genuine effort to hire and retain female officers should be used to establish that a university has sought to address the effects of campus assault and prevent its recurrence under Title IX. According to the OCR, schools must take prompt action once they have notice of a hostile environment to avoid violating Title IX. ${ }^{235}$ Given the disparate impact of sexual assault on women students, the large percentage of women students at most co-educational colleges, and research indicating that increases in the number of women officers results in increased reporting of sexual assault and crimes against women, universities can demonstrate that they have worked to remedy or prevent a hostile environment by hiring, training, and retaining women officers. Failure to do so represents a missed opportunity that may well come back to harm a university and the students whom it is charged to protect. Reports indicate that colleges that have been investigated for Title IX violations have subsequently acted to make changes on campus to cure the alleged hostile environment. ${ }^{236}$ Some universities have followed OCR guidelines and VAWA requirements and hired Title IX coordinators; written and widely disseminated university policies and resources; trained students and staff; strengthened primary prevention efforts; and worked to increase bystander intervention. ${ }^{237}$ Without question, these are all important components of a safe campus community. A true culture shift, however, requires going beyond mere compliance with federal mandates to change campus culture and foster a climate that truly encourages reporting. ${ }^{238}$

${ }^{235}$ Dear Colleague Letter, supra note 27, at 15; see also Revised Sexund. HarAssment GUIDANCE, supra note 54, at 12 ("As long as the school, upon notice of the harassment, responds by taking prompt and effective action to end the harassment and prevent its recurrence, the school has carried out its responsibility under the Title IX regulations.").

${ }^{236}$ See, e.g., Title IX: Sexual Harassment: State University of New York (SUNY): (0211-6001), U.S. Dep'T of EDuc. (Mar. 4, 2014), http://www2.ed.gov/about/offices/list/ocr/ docs/investigations/02116001.html, archived at http://perma.cc/FX32-SZDJ; Title IX: Sexual Harassment: University of Montana-Missoula (MT): (1012600I), U.S. DEP'T OF EDuc. (Sept. 16, 2013), http://www2.ed.gov/about/offices/list/ocr/docs/investigations/101 26001 html, archived at http://perma.cc/JX28-JTLT; Title IX: Sexual Harassment: University of Notre Dame - Notre Dame (IN): (\#05-11-6901), U.S. Dep'T or Educ. (Sept. 12, 2012), http://www2.ed.gov/about/offices/list/ocr/docs/investigations/05072011.html, archived at http://perma.cc/Y7YX-4DTX.

${ }^{237}$ See Am. Council On Educ., New Requirements Imposed by the Violence Against Women Reauthorization ACt 3 (2014), archived at http://perma.cc/A6FK EUJS; Dear Collengue Letter, supra note 27, at 7, 14-16; Meredith Clark, College Sexual Assault: A Campus-by-Campus Report Card, mSNBC (Aug. 26, 2014), http://www .msnbc.com/ronan-farrow-daily/college-sexual-assault-campus-campus-report-card, archived at http://perma.cc/P9T7-AJRE (listing over two dozen colleges and their actions to address Title IX deficiencies).

${ }^{238}$ Gina Maisto Smith \& Leslie Marie Gomez, Effiective Implementation of the Institutional Response to Sexual Misconduct Under Title IX and Related GuIDANCE 27 (2013), available at http://www.higheredcompliance.org/resources/resources/05D_13-06-38.pdf ("Through commitment, coordination, and competence, colleges and universities can ... provide ... [a] response to sexual misconduct that is rooted in a culture of prevention and intervention and a climate that encourages reporting ....."). 
Universities have publicly declared that they understand that fixing the problem of sexual assault on campus is vital. For example, Amherst College announced that, with respect to Title IX, "We are deeply committed to meeting all the requirements of federal law and, more than that, holding ourselves to the highest possible standards in meeting the needs of our students." ${ }^{239}$ Princeton University President Christopher L. Eisgruber issued a statement about the university's "determination to ensure a campus climate that places high priority on prevention and support and on ensuring safety." ${ }^{240}$ As universities take a hard look at their campus policies and procedures, they must look to changing their culture as well. When a university under investigation has been encouraged to "enhance its outreach to . . . students," 241 for example, such "outreach" should include hiring more female campus officers to demonstrate that the administration understands the critical role that campus police agencies play in setting the tone for the campus culture.

Hiring trained women officers throughout the campus sends a strong message to every member of the campus community that women's authority, independence, and autonomy are a core part of the university's institutional values. Thus, not only does the presence of female officers reflect the university's commitment to preventing sexual assault, it also communicates an institutional tone ${ }^{242}$ of valuing women's lives. Rape is about the devaluing of these lives, the objectification of women's bodies, ${ }^{243}$ and uncontrolled, entithed perpetrators ${ }^{244}$ who believe that they can commit these crimes unfettered in a campus culture. Women on campus are not the property of men on campus. $^{245}$ As the National Association of College and University Attorneys

${ }^{239}$ Jack Flynn, Amherst College, Responding to Federal Title IX Probe, Cites Major Improvements in Its Handling of Sexual Assault Complaints, MassLive (May 2, 2014), http://www.masslive.com/news/index.ssf/2014/05/amherst_college_responding_to.html, archived at http://perma.cc/U6SM-ZFLJ (emphasis added) (quoting Caroline Hanna, the college's associate director of public affairs).

${ }^{240}$ Office of Commc'ns, OCR Conducts Investigation; New Agreement Brings Princeton into Title IX Compliance, PrinCETON UnIV. (Nov. 5, 2014), http://www .princeton.edu/main/news/archive/S41/52/07K45/index.xml?section=topstories, archived at http://perma.cc/X6YL-CTTU.

${ }^{241}$ Letter from Thomas J. Hibino, supra note 223, at 24.

${ }^{242}$ SMITH \& Gomez, supra note 238, at 28 (discussing advocacy by National Association of College and University Attorneys to foster change in college climates through a variety of actions, including setting the "tone at the top" and allocating sufficient resources to the mission).

${ }^{243}$ See, e.g., Kristina Malinauskaite, Perpetuation of Sexual Objectification \& Silencing of Women 3 (unpublished manuscript), available at http://www.academia.edu/ 6302524/Perpetuation_of_Sexual_Objectification_and_Silencing_of_Women (stating that the unfortunate consequence of the sexual objectification of women is that many offenders feel that they have a right to a woman's body, that somehow it is theirs for the taking).

${ }^{244}$ Patricia McGuire, College Presidents Must Lead on Sexual Assault, HufFington Post (Nov. 1, 2014), http://www.huffingtonpost.com/patricia-mcguire/college-presi dents-must-I_b_5744646.html, archived at http://perma.cc/6VAL-CURG.

${ }^{245}$ In an attempt to increase women's safety, some sororities have considered hosting house parties where alcohol is served. Alan Schwarz, Sorority Anti-Rape Idea: Drinking 
points out, the fact that universities are responsible for the prevention, investigation, evaluation, and adjudication of sexual assault allegations is a paradigm shift from what might be considered traditional roles of college campuses. ${ }^{246}$ In this new role, the culture, climate, and values of an institution are just as important as the procedures and policies it follows. They are all part of a coordinated and integrated institutional response to the reality of campus rape..$^{247}$

\section{ConCLusion}

The scourge of sexual assault continues to afflict university campuses across the nation. Though the vast majority of victims are female, women are generally woefully underrepresented in campus law enforcement agencies. We do not argue, however, that the ranks of women in these agencies should be increased simply for the sake of attaining a more demographically reflective police force as an end in itself. Rather, a demonstrable connection exists between the disproportionately low number of women among campus police and the troublingly low reporting rates for sexual assault, and these chronically low rates in turn severely impair universities' ability to grapple with this crime. ${ }^{248}$ Conversely, research shows that a higher proportion of female officers tends to increase women's reporting rates. ${ }^{249}$ On college campuses, this effect would improve efforts to curb and punish sexual violence.

We also believe that a university's failure to take reasonable measures to address sexual assault can contribute to a hostile environment for women as that term is defined by Title IX of the Education Amendments of 1972. Accordingly, we would propose that the Department of Education Office of Civil Rights take immediate steps to recommend that publicly funded colleges and universities demonstrate consistent and ongoing efforts to hire and

on Own Turf, N.Y. Times (Jan. 19, 2015), http:/www.nytimes.com/2015/01/20/us/sorority-anti-rape-idea-drinking-on-own-turf.html, archived at http://perma.cc/D6N2-YSNT. Such parties have traditionally been the exclusive enclave of fraternities, which have not only controlled the physical premises but also prescribed the terms of the event-e.g., women's attire. See Amanda Hess, Sorority Girls Fight for Their Right to Party, S।.ATE (Jan. 20, 2015), http://www.slate.com/blogs/xx_factor/2015/01/20/campus_rape_sorori ties_want_to_fight_sexual_assault_by_throwing_their_own.html, archived at http://per ma.cc/ZC7R-8297 (discussing "Hunt or Be Hunted" themed fraternity parties, where women are cast in the role of prey). As a result, some women seek to regain a "home-court advantage" as sorority party hosts in order to gain more ownership over their participation in the campus social scene. Vivian Nunez, Sororities Want Home Field Advantage When It Comes to Campus Parties, Generation Progress (Jan. 29, 2015), http://genprogress.org/voices/2015/01/29/34463/sororities-want-home-field-advantage-when-itcomes-to-campus-parties/, archived at http://perma.cc/GKR6-H4NM.

${ }^{246}$ SMITH \& GoMEZ, supra note 238, at 1-2 (stating the importance of schools' combining distinct concepts of legal mandates, dynamics of sexual assault, and campus culture, resources, and values to develop a coordinated campus response to sexual assault).

${ }^{247} I d$. at 3.

${ }^{248}$ See supra Part II.

${ }^{249}$ See supra notes $149-53$ and accompanying text. 
retain sworn women law enforcement officers. Such efforts would serve as a vital tool in the effort to ensure that women students increase reporting of sexual violence on the nation's campuses. This increase would help to produce justice in individual cases, serve as a deterrent to potential perpetrators, and thus ultimately help secure for women students that equality on campus which is their legal and moral right. 